ECCOMAS

Proceedia
COMPDYN 2021

$8^{\text {th }}$ ECCOMAS Thematic Conference on Computational Methods in Structural Dynamics and Earthquake Engineering M. Papadrakakis, M. Fragiadakis (eds.) Streamed from Athens, Greece, 28 - 30 June 2021

\title{
DESIGN AND ANALYSIS OF FREEDAM FRAMES: COMPARISON WITH TRADITIONAL CONNECTIONS
}

\author{
Maria Maglio, Camilla Naddei, Elide Nastri, Rosaria Russo, Paolo Todisco
}

Department of Civil Engineering, University of Salerno

Via Giovanni Paolo II, 132, 84084, Fisciano (SA), Italy

e-mail: enastri@unisa.it

\begin{abstract}
The aim of this work is to present the results of the design of Moment Resisting Frames and Dual-Concentrically Braced Frames (D-CBFs) according to the Theory of Plastic Mechanism Control. These frames are equipped with both haunched connections, analysed in the framework of the RFCS founded EqualJoints Plus research project, and FREEDAM joints analysed in the framework of the RFCS founded FREEDAM Plus. The seismic performances of the structures are investigated by both pushover and nonlinear dynamic analyses.
\end{abstract}

Keywords: Prequalified connections, Concentrically Braced Frames, TPMC, Dual Systems, seismic response, FREEDAM Plus. 


\section{INTRODUCTION}

The design of modern seismic resistant structures is based on a preliminary selection of the so-called dissipative zones which must be designed to assure, by means of their plastic engagement, the dissipation of the earthquake input energy. It is well known that Moment Resisting Frames (MRFs) [1]-[4] are characterized by a limited lateral stiffness and high ductility linked to the possibility of forming many plastic hinges. The location of such dissipative zones at the beam ends is commonly preferred by designing full-strength beam-tocolumn joints. It is recommended that beam-to-column joints are designed with sufficient over-strength with respect to the connected beams to assure their yielding accounting for the influence of random material variability and for strain-hardening occurring before the complete development of the ultimate flexural resistance of plastic hinges.

Dual Concentrically Braced Frames (D-CBFs) [6]-[7] constitute an appealing structural scheme because they combine the advantages of MRFs, which are characterized by high global ductility due to the high number of dissipative zones, and CBF, which are characterized by high lateral stiffness due to the exploitation of the axial stiffness of diagonal members. In fact, thanks to bracing members, providing additional lateral stiffness, D-CBFs allow respecting serviceability code requirements. However, they are penalized by the occurrence of buckling of bracing members in compression which governs the shape of the hysteresis loops of such dissipative zones [8]-[14]. D-CBFs are also attractive for collapse prevention requirements because they allow exploiting the local ductility supply of the MR part thus giving to the diagonal members only the stiffening task. This observation suggests a design approach where the braced frame is dimensioned to satisfy serviceability requirements while the moment resisting part is designed to satisfy ultimate limit state requirements.

It is known that, to prevent catastrophic collapses, the structural system and members should have enough strength and ductility to resist to earthquakes [15]-[23]. Therefore, a stable and reliable capacity for energy dissipation should be provided through proper design and detailing of the system, members, and joints. These latter attracted much attention because an improper design or fabrication of the connections may lead to the collapse failure of the whole structure.

In this paper, reference is made to the use of full-strength joints [24]-[30] that has been always considered the best way to dissipate the seismic input energy. In particular, the joint typology herein investigated is the so-called "haunched" connections which are characterized by a haunch at the lower flange of the beam having the aim of increasing the connection stiffness thus allowing the yielding in the beam ends. As regards code provisions, UNI EN 19931-8 [31] provides design rules and analytical models to predict the mechanical behavior of the joints; while UNI EN 1998-1 [32] provides additional design rules for seismic resistant joints. From the existing scientific literature, a wide data base of experimental results on beam-tocolumn joints is available [33]. Moreover, several research projects have been developed and devoted to investigating the beam-to-column joints behavior under both seismic and nonseismic loadings. Even though these projects have provided a large amount of data dealing with steel beam-to-column connections, none of the existing European studies has been aimed at prequalifying specific configurations for seismic areas based on parametric experimental investigations. In order to fill these gaps, the recently finished European research project EQUALJOINTS [34] was aimed at providing prequalification criteria of steel joints for the next version of UNI EN 1998-1 [32]. The following dissemination project EQUALJOINTSPLUS [35]-[38], had the scope to promote the valorisation and dissemination of the technical knowledge and the design tools developed within the EQUALJOINTS project. The goal is to reach a wider and easier use of dissipative beam-to-column connections in steel seismic resist- 
ing systems in Europe. The joint typologies selected for prequalification procedure are representative of those most adopted in European practice. In the context of the research project EQUALJOINTS [34], four types of prequalified connections are considered. In particular, three types of prequalified bolted beam-to-column joints (Figure $1 \mathrm{a}, \mathrm{b}$ and $\mathrm{c}$ ) will be considered, as well as welded dog-bone beam-to-column joint made of heavy sections (Figure $1 \mathrm{~d}$ ). In this paper, reference is made to "haunched" connections (Figure $1 \mathrm{a}$ ).

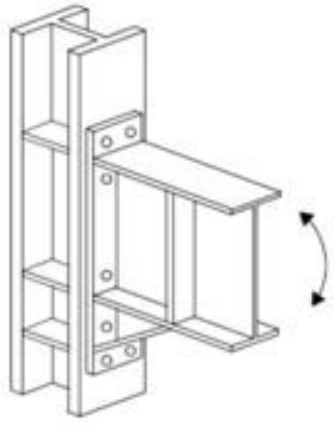

(a)

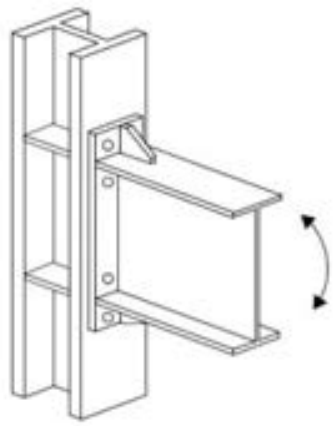

(b)

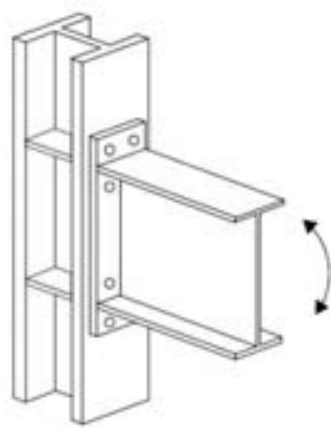

(c)

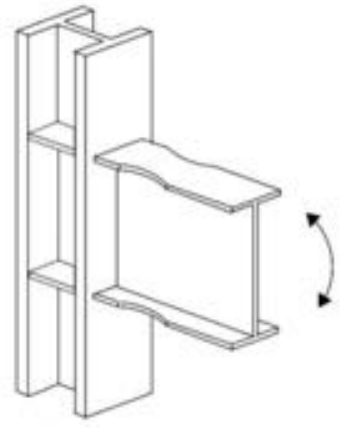

(d)

Figure 1: Beam-to-column joints investigated in the framework of EQUALJOINTS project: a) Bolted haunched joints; b) Bolted extended stiffened end-plate joint; c) Bolted extended unstiffened end-plate joint; d) Welded dog-bone joint

However, independently of the use of either full-strength or partial-strength beam-tocolumn joints, the main drawback of the traditional seismic resistant design strategy is intrinsic in the strategy itself. The structural damage is essential to dissipate the earthquake input energy but, on the other hand, it is the main source of direct and indirect losses. For this reason, many researchers have focused their attention on the strategy of supplementary energy dissipation with the aim to reduce the structural damage under destructive seismic events and, therefore, the direct and indirect losses. This strategy is based on the use of specific energy dissipation devices which have to be inserted between couples of points of the structural scheme for which high relative displacements or velocities are expected under the action of severe ground motions. In this work, reference is made to beam-to-column FREEDAM [39] connections that have been widely tested at the Laboratory of Materials and Structures of University of Salerno and to FREEDAM connections equipping the intersection between the diagonals of chevron brace frames (CBFs) when the structure is not a simple Moment resisting frame (MRF) but dual systems given by the combination of MRFs and CBFs.
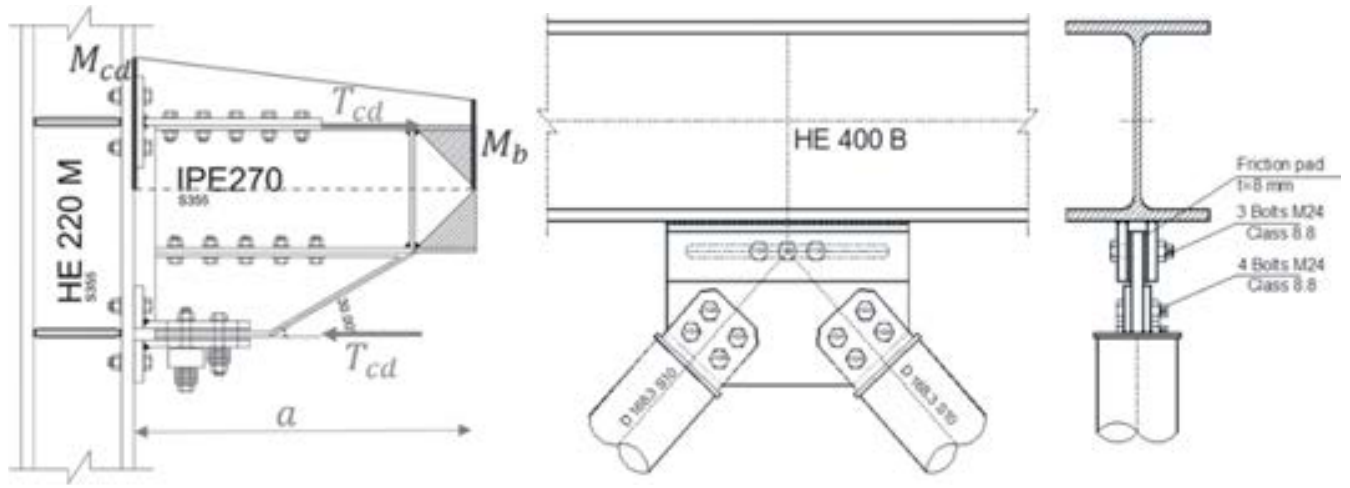

Figure 2: Beam-to-column joints investigated in the framework of FREEDAM plus project: a) MRF FREEDAM joint; b) FREEDAM friction damper to chevron brace. 
The scope of the paper is investigating the influence of both the mentioned connection typologies in the seismic response of MRFs and D-CBFs. To this scope, medium-rise structures have been designed according to the Theory of Plastic Mechanism Control (TPMC) design approach [40]-[49], which is a powerful design. The structural response was analysed by means of both non-linear static and dynamic analyses. All the activities described in this work are performed in the framework of the RFCS Project FREEDAM Plus [50] aimed at the valorisation and dissemination of the technical knowledge and the design tools developed within FREEDAM project, to reach a wider and easier use of dissipative beam-to-column connections in steel seismic resisting systems.

\section{HAUNCHED CONNECTIONS VS FREEDAM CONNECTIONS}

Bolted joints are very interesting for practice in steel buildings, owing to their inherent advantages not only in terms of high-quality execution (e.g. shop welding and bolting on site), but also highly productive erection (less time-consuming). Full strength joints are designed to guarantee the formation of all plastic deformations into the beam, which is consistent with EN 1998 strong column-weak beam capacity design rules (i.e. non-dissipative joint).

"Haunched" connections [51] increasing the web depth also makes an increase of the height of panel zone, which reduces the panel zone yielding. In that case a greater beam plastic rotation is needed to achieve an equivalent seismic energy dissipation. Application of the haunches assures that plastic hinges form in the beams which increases the global seismic performance of steel moment resisting frames. Appropriate detailing and use of "haunched" joints could be an effective way for ductile design of steel frames. The haunched connection used in this paper is described in Figure 3 where $M_{j, R d}^{n}$ is the joint resistance, $M_{p l, b, c f, R d}^{e}$ is the beam resistance. All the prequalifying requirements reported in Figure 3 are finalized to the stiffening of the panel zone whose strength is also calibrated not to yield in case of destructive seismic events.

\begin{tabular}{|c|c|c|c|c|c|}
\hline \multirow{2}{*}{$\begin{array}{l}\text { Joint } \\
\text { Type }\end{array}$} & \multirow{2}{*}{ Geometry } & \multicolumn{2}{|c|}{ Strength } & \multicolumn{2}{|c|}{ Stiffness } \\
\hline & & Connection: & Panel Zone: & Connection: & Panel Zone: \\
\hline \multirow{2}{*}{$\begin{array}{l}\text { EH-S: } \\
\text { Full- } \\
\text { strength } \\
\text { with } \\
\text { strong } \\
\text { panel } \\
\text { zone }\end{array}$} & \multirow{2}{*}{$\begin{array}{c}\frac{h_{h}}{h_{b}}=0.45 \\
\frac{s_{h}}{h_{b}}=0.65 \\
z_{w p}=h_{b}+h_{h}\end{array}$} & \multirow{2}{*}{$\frac{M_{j, R d}^{n}}{M_{p l, b, c f, R d}^{e}}=1.3$} & $\begin{array}{c}\text { External nodes: } \\
\frac{V_{w p, R d}^{n} \cdot z_{w p}}{M_{p l, b, c f, R d}^{e}}=1.65\end{array}$ & \multirow{2}{*}{$\frac{s_{\text {con,ini }}}{s_{b}}=80$} & $\begin{array}{c}\begin{array}{c}\text { External } \\
\text { nodes: }\end{array} \\
\frac{s_{w p, i n i}}{s_{b}}=55\end{array}$ \\
\hline & & & $\begin{array}{c}\text { Internal nodes: } \\
\frac{V_{w p, R d}^{n} \cdot z_{w p}}{2 \cdot M_{p l, b, c f, R d}^{e}}=1.65\end{array}$ & & $\begin{array}{c}\begin{array}{c}\text { Internal } \\
\text { nodes: }\end{array} \\
\frac{s_{w p, i n i}}{2 \cdot s_{b}}=55\end{array}$ \\
\hline
\end{tabular}

Figure 3: Details of "Haunched" connections

FREEDAM connections, studied in the framework of the recently accomplished homonymous project (RFSR-CT-2015-00022) have a wide-ranging use because it is a technology that 
can be used both in the construction of new buildings and for the seismic rehabilitation of existing buildings. From the technological point of view, the innovation regards the conception of beam-to-column connections. In fact, beam-to-column connections are equipped with friction dampers which can be located either at the bottom flange level or at the levels of both the flanges. Such friction dampers must be designed to assure the transmission of the beam bending moment required to fulfil serviceability limit state requirements and to withstand without slippage the gravity loads. In addition, they must be designed to assure the dissipation of the earthquake input energy, corresponding to the collapse prevention limit state, without any damage. FREEDAM joints are extremely robust, because they are characterized by a first phase of the response corresponding to the damper slippage and by a second phase in which a secondary resisting mechanism is activated with the bolts acting in shear and the plate elements subjected to bearing. The added value to what has already been achieved at both European and worldwide level is the increase the safety buildings and reduction of the direct and indirect costs related to the development of structural damage in case of rare seismic events or exceptional loads. The friction resistance is calibrated by acting on the number and diameter of bolts and their tightening torque governing the preloading. The flexural resistance results from the product between the damper friction resistance and the lever arm. Such connections exhibit wide and stable hysteresis loops without any damage to the connection steel plate elements, so that they can be referred as "Free from Damage Connections".

FREEDAM joints can be designed according to the following equation:

$$
M_{f . E d} \leq M_{f . R d}=\frac{\mu_{s t} n_{b} n_{s} P_{f}}{\gamma_{F 2}} h_{f}
$$

where $\mu_{s t}$ is the average value of the static friction coefficient equal to $0.76, n_{b}$ is the number of bolts, $n_{s}$ is the number of the contact surfaces equal to $2, h_{f}$ is the lever arm given as the sum of $\mathrm{H}$ (Figure 14) and $h_{b}$ (height of the beam), $\gamma_{F 2}$ is the partial safety factor accounting for the randomness of friction and bolt preload, and it is equal to $1.26, P_{f}$ is the preloading force that has to be calibrated to assure that the FREEDAM connection resistance is as much close as possible to the design moment $M_{f . E d}$ at the column face resulting from the seismic load combination. Therefore:

$$
P_{f} \cong \frac{M_{f . E d} \gamma_{F 2}}{\mu_{s t} n_{b} n_{s} h_{f}}
$$

The bolt preloading should be between $40 \%$ and $100 \%$ of the maximum bolt preloading allowed by code provisions (EN 1993-1-8).

The number of bolts changes according to the standardised devices (Table 1). The friction damper to be adopted must be selected in function of the beam height $h_{b}$ and of the increase of the lever arm due to the haunch resulting from the damper geometry (Figure 4).

\begin{tabular}{|c|c|}
\hline Device & $\begin{array}{c}\text { Number of bolts } \\
n_{b}\end{array}$ \\
\hline D1 & 4 \\
\hline D2 & 4 \\
\hline D3 & 6 \\
\hline D4 & 8 \\
\hline D5 & 8 \\
\hline
\end{tabular}

Table 1: Number of bolts of the prequalified devices 


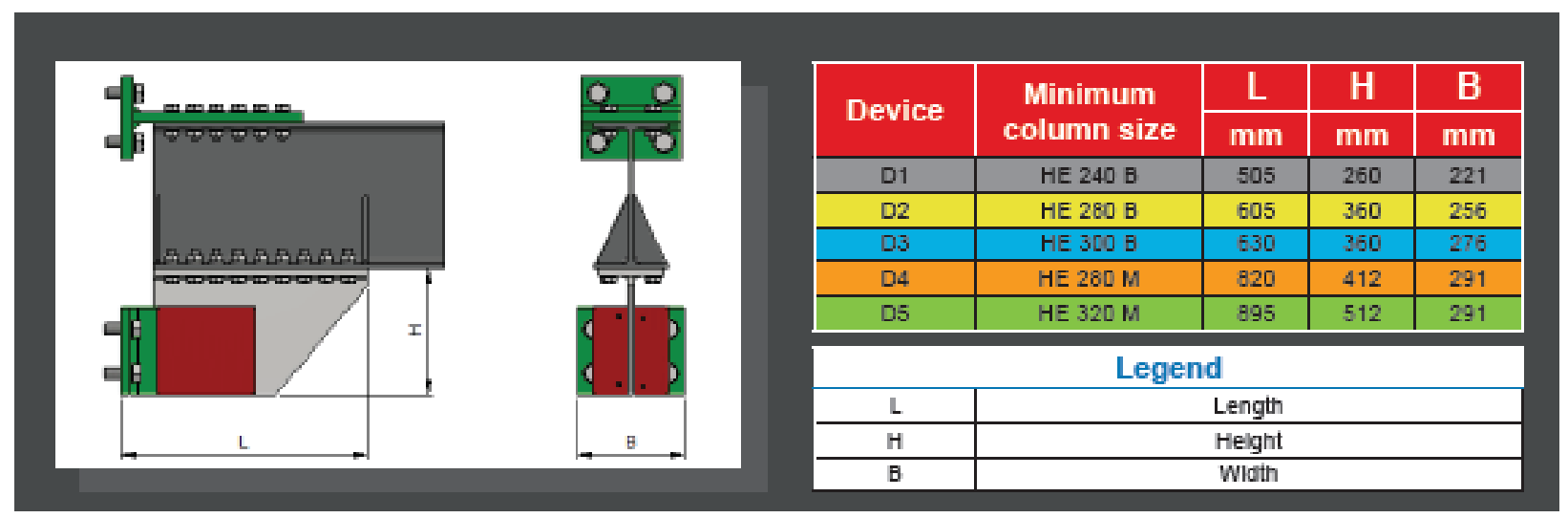

Figure 4: Dimension of prequalified FREEDAM connections

It is important underlining the need to perform a local hierarchy criterion to prevent the beam yielding that can be expressed as follows:

$$
M_{b . R d} \geq \gamma_{r m} M_{f \cdot R d}\left(\frac{l-L}{l}\right)
$$

where $\gamma_{r m}=1.60$ [52], $M_{b . R d}$ is the beam plastic moment, $M_{f . R d}$ is the FREEDAM joint resistance (Eq. (1)), $l$ is the beam length and $L$ is the device dimension as reported in Figure 4.

\section{DESIGN APPROACH}

The design approaches herein proposed regard the Theory of Plastic Mechanism Control [40], [53]-[56]. The Theory of Plastic Mechanism Control is a design approach based on a rigorous theoretical background. It assures the development at collapse of a mechanism of global type. TPMC exploits the kinematic theorem of plastic collapse extended to the concept of mechanism equilibrium curve:

$$
\alpha=\alpha_{0}-\gamma \delta
$$

where, following the theory of rigid-plastic analysis, $\alpha_{0}$ is the first order collapse multiplier of horizontal forces, $\gamma$ is the slope of the linearized mechanism equilibrium curve due to second order effects and $\delta$ is the plastic top sway displacement. It means that in the case of the global mechanism Eq. (3) becomes:

$$
\alpha^{(g)}=\alpha_{0}^{(g)}-\gamma^{(g)} \delta
$$

while in the case of undesired mechanism becomes:

$$
\alpha_{i_{m}}^{(t)}=\alpha_{0 . i_{m}}^{(t)}-\gamma_{i_{m}}^{(t)} \delta
$$

where $\alpha_{0}^{(g)}$ and $\alpha_{0 . i_{m}}^{(t)}$ are the first order collapse mechanism multipliers for global and undesired mechanism, respectively; $\alpha^{(g)}$ and $\alpha_{i_{m}}^{(t)}$ are the collapse multiplier of horizontal force for the global and undesired mechanism, respectively and $\gamma^{(g)}$ and $\gamma_{i_{m}}^{(t)}$ are the slope of mechanism equilibrium curve for the global and undesired mechanism, respectively. TPMC states that the mechanism equilibrium curve corresponding to the global mechanism (Eq. (4)) has to be located below those corresponding to all the undesired mechanisms (Eq. (5)) until a design displacement $\delta_{u}$ compatible with the local ductility supply (Figure 5). The column sections at each storey that guarantee a global collapse mechanism are the unknowns of the design problem, while the dissipative zones are preliminarily designed according to the first principle of capacity design. In this paper, the ultimate design displacement $\delta_{u}$ is computed as:

$$
\delta_{u}=\theta h_{n s}
$$


where $\theta$ is the target rotation of the plastic hinge that is assumed equal to $0.04 \mathrm{rad}$ neglecting the higher stiffness of braces, and $h_{n s}$ is the building height. The plastic hinge rotation is set equal to the interstorey drift ratio, since the idealized behavior of the structure is rigid-plastic. It is worth noting that P-Delta second order effects are taken into account using the TPMC design approach and, as a consequence, does not deeply affect the design as the use of the $\theta$ [57] factor proposed in the framework of Eurocode 8 [32], thus allowing to optimize the design overstrength of the structure and the non-linear response as well.

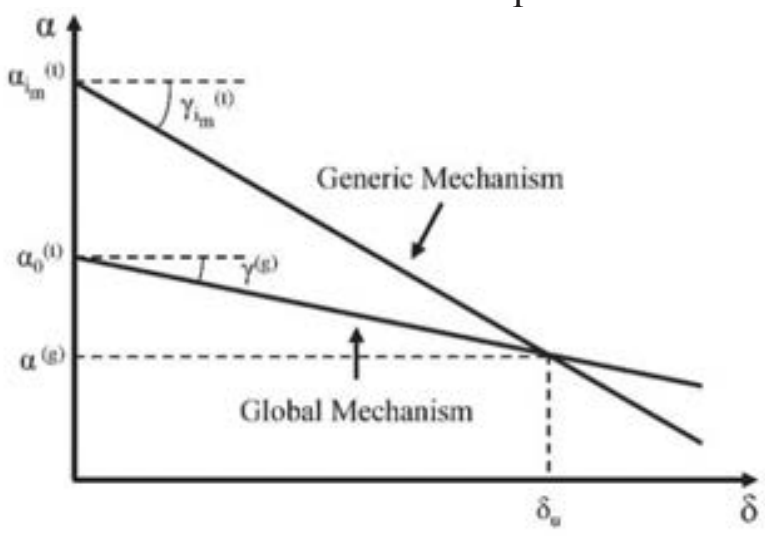

Figure 5: TPMC statement.

\section{STUDY CASE}

The seismic resistant structural system is a perimeter seismic resistant system. The inner bays are pinned and designed for gravity loads only. The building has 4 storeys and 4 bays. The bay span is equal to $6.00 \mathrm{~m}$; the interstorey height is equal to $3.50 \mathrm{~m}$. Stairs are located outside the analysed building by means of an independent structure as the same as the elevator. The seismic resistant scheme of the building is depicted in Figure 6 for $\mathrm{X}$ direction. The elevation configuration is reported in Figure 7. The material adopted for the structure is steel grade S355 using a partial safety factor equal to 1, so the nominal yield stress is $355 \mathrm{MPa}$ for beams and for columns. The following permanent loads are considered:

- Permanent loads on floors and roof: $3,25+0,75=4,0 \mathrm{kN} / \mathrm{m}^{2}$

- Permanent loads of external walls: $1,0 \mathrm{kN} / \mathrm{m}^{2}$

while the live loads are equal to $3.50 \mathrm{kN} / \mathrm{m}^{2}$ for current floors and 3.00 for $\mathrm{kN} / \mathrm{m}^{2}$ for the roof.

The design horizontal forces have been determined according to the new Eurocode $8 \mathrm{draft}$ [58] spectra assuming a reference spectral acceleration at plateau of $8.5 \mathrm{~m} / \mathrm{s}^{2}$, a behaviour factor equal to 6.5 for MRFs and D-CBFs with FREEDAM joints and 4.8 for D-CBFs with traditional haunched connections.

Serviceability requirements have been checked by response spectrum anaysis to compute the elastic displacements and to derive the interstorey drift values to be compared with the corresponding limits according to:

$$
d_{r}=0.020 h
$$

where $d_{r}$ is the relative displacement increased by the behaviour factor and $\mathrm{h}$ is the interstorey height. The limitation is the one reported into the new Eurocode 8 draft [59]. 


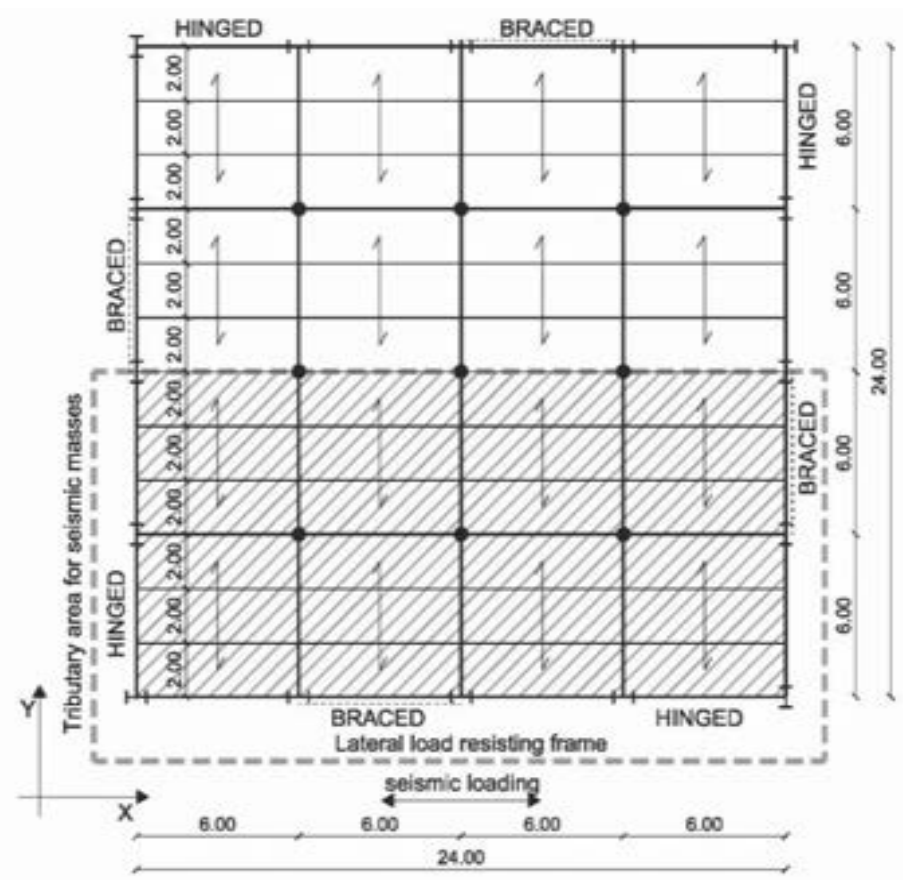

Figure 6: Plan configuration of the building with identification of the lateral load resisting system
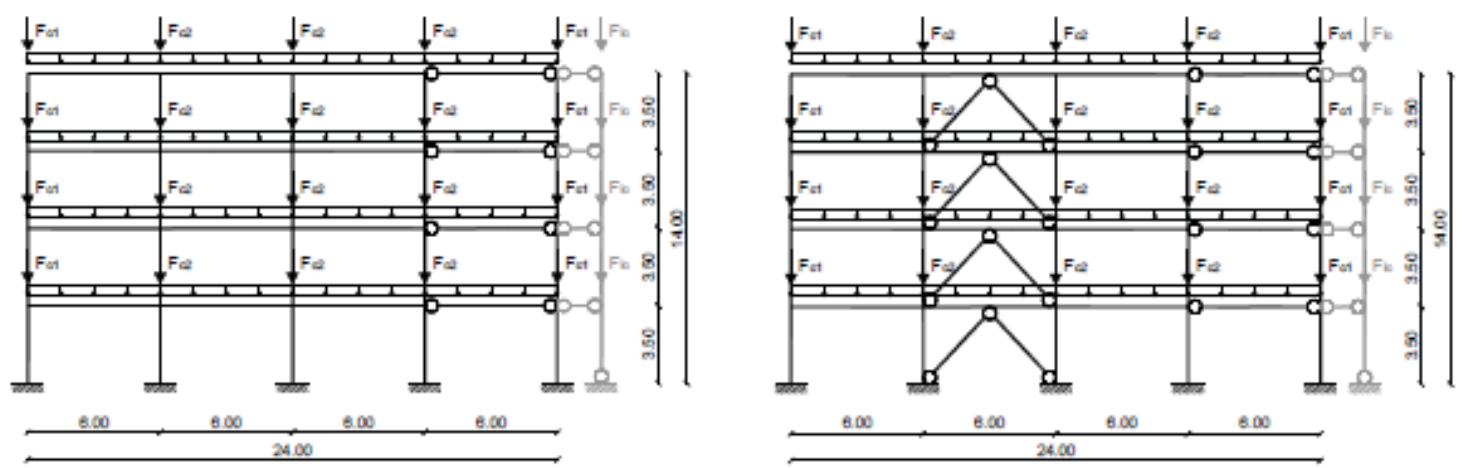

Figure 7: Elevation configuration of the building (MRFs and D-CBFs)

\section{DESIGNED STRUCTURES}

This section summarizes the description of the MRFs and Dual-CBFs designed according to TPMC and equipped with both haunched and FREEDAM connections.

\begin{tabular}{ccccc}
\hline Storey & Bay 1 & Bay 2 & Bay 3 & Bay 4 (pinned) \\
\hline $1-2$ & IPE 330 haunched & IPE 330 haunched & IPE 330 haunched & IPE 220 \\
\hline 3-4 & IPE 300 haunched & IPE 300 haunched & IPE 300 haunched & IPE 220 \\
\hline Storey & Column 1-5 & Column 2 & Column 3 & Column 4 \\
\hline $1-2$ & HE 340 B & HE 340 B & HE 340 B & HE 340 B \\
\hline 3-4 & HE 320 B & HE 320 B & HE 320 B & HE 320 B \\
\hline
\end{tabular}

Weight of structural elements: $12876 \mathrm{~kg}$

Table 2: Beam and column sections for 4 St_DC3_MRFs_X_TRADITIONAL

\begin{tabular}{ccccc}
\hline Storey & Bay 1 & Bay 2 & Bay 3 & Bay 4 (pinned) \\
\hline \multirow{2}{*}{$1-2$} & IPE 330 & IPE 330 & IPE 330 & IPE 220
\end{tabular}




\begin{tabular}{ccccc}
$3-4$ & IPE 300 & IPE 300 & IPE 300 & IPE 220 \\
\hline Storey & FREEDAM & FREEDAM & FREEDAM & Column 1-5 \\
\hline $1-2$ & HE 300 B & HE 300 B & HE 300 B & HE 300 B \\
\hline $3-4$ & HE 260 B & HE 260 B & HE 260 B & HE 260 B \\
\hline
\end{tabular}

Weight of structural elements: $11500 \mathrm{~kg}$

Table 3: Beam and column sections for 4 St_DC3_MRFs_X_FREEDAM

\begin{tabular}{ccccc}
\hline Storey & Bay 1 & Bay 2 & Bay 3 & Bay 4 (pinned) \\
\hline $1-2$ & IPE 330 haunched & IPE 270 haunched & IPE 330 haunched & IPE 220 \\
\hline $3-4$ & IPE 330 haunched & IPE 270 haunched & IPE 330 haunched & IPE 220 \\
\hline Storey & Column 1-5 & Column 2 & Column 3 & Column 4 \\
\hline $1-2$ & HE 360 B & HE 450 B & HE 450 B & HE 450 B \\
\hline $3-4$ & HE 320 B & HE 450 B & HE 450 B & HE 450 B \\
\hline Storey & Diagonal & & & \\
\hline $1-2$ & CHS 88.9x5 & & & \\
\hline $3-4$ & CHS 88.9x4 & & & \\
\hline
\end{tabular}

Weight of structural elements: $14951.8 \mathrm{~kg}$

Table 4: Beam, diagonal and column sections for 4 St_DC3_D-CBFs_X_TRADITIONAL

\begin{tabular}{|c|c|c|c|c|}
\hline Storey & Bay 1 & Bay 2 & Bay 3 & Bay 4 (pinned) \\
\hline $1-2$ & $\begin{array}{c}\text { IPE } 360 \\
\text { FREDDAM }\end{array}$ & $\begin{array}{c}\text { IPE } 360 \\
\text { FREEDAM }\end{array}$ & $\begin{array}{c}\text { IPE } 360 \\
\text { FREEDAM }\end{array}$ & IPE 220 \\
\hline $3-4$ & $\begin{array}{c}\text { IPE } 330 \\
\text { FREEDAM }\end{array}$ & $\begin{array}{c}\text { IPE } 330 \\
\text { FREEDAM }\end{array}$ & $\begin{array}{c}\text { IPE } 330 \\
\text { FREEDAM }\end{array}$ & IPE 220 \\
\hline Storey & Column 1-5 & Column 2 & Column 3 & Column 4 \\
\hline $1-2$ & HE $300 \mathrm{~B}$ & HE $300 \mathrm{~B}$ & HE $300 \mathrm{~B}$ & HE $300 \mathrm{~B}$ \\
\hline $3-4$ & HE $260 \mathrm{~B}$ & HE $260 \mathrm{~B}$ & HE $260 \mathrm{~B}$ & HE 260 B \\
\hline Storey & Diagonal & & & \\
\hline 1 & CHS $114.3 \times 6.3$ & & & \\
\hline 2 & CHS $114.3 \times 5$ & & & \\
\hline 3 & CHS $114.3 \times 4$ & & & \\
\hline 4 & CHS 88.9x5 & & & \\
\hline
\end{tabular}

Weight of structural elements: $12486 \mathrm{~kg}$

Table 5: Beam, diagonal and column sections for 4 St_DC3_D-CBFs_X_FREEDAM

Figure 8 shows the comparison in terms of weight among MRFs and D-CBFs equipped with haunched and FREEDAM connections. It is evident that in both cases the structures with traditional connections leads to heavier structures. 


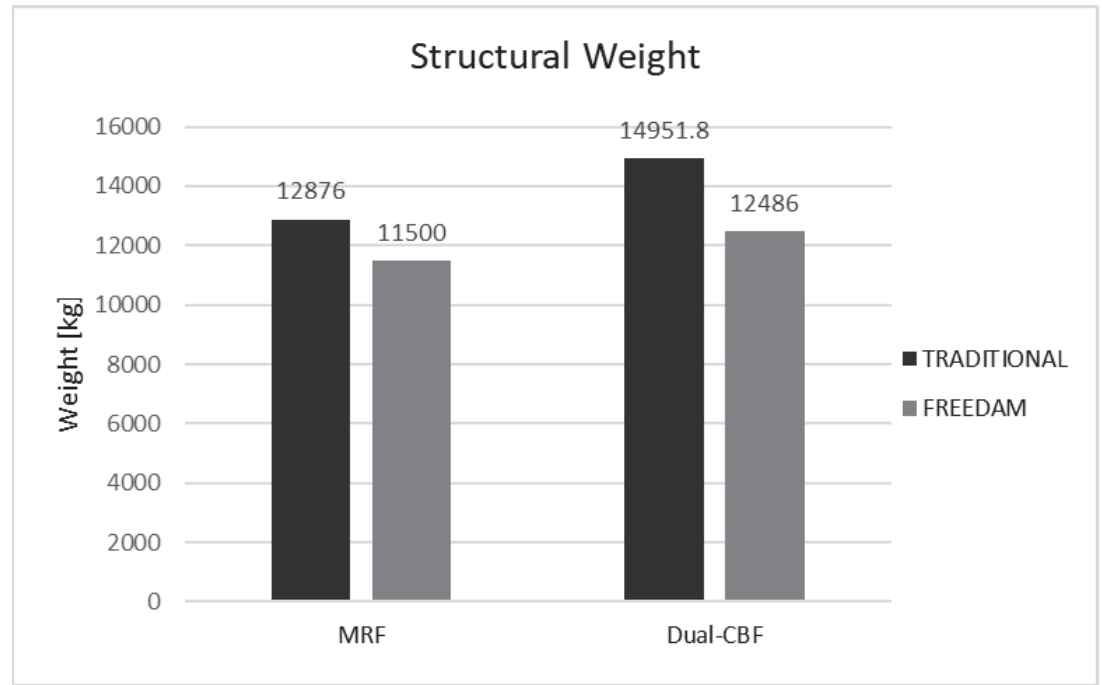

Figure 8: Comparison in terms of weight among MRFs and D-CBFs equipped with haunched and FREEDAM connections designed according to TPMC.

\section{MODELING ASSUMPTIONS}

The modelling of these structures is carried out in SAP 2000 ambiance [60] according to the scheme reported in Figure 7. The leaning column (Figure 7) is used to consider the vertical loads acting on the frame (including masses) and the second order effects. The material steel grade is S355 where the coefficients 1.20 and 1.10 are the overstrength factor due to random material variability according to the Probabilistic TPMC [49] and the strain hardening, respectively. [61]-[66]. The plastic behaviour of members has been modelled in terms of lumped plasticity by P-hinge properties.

\subsection{Structures with traditional joints}

Beams and columns have been modelled by means of beam-column elements, whose non linearities have been concentrated in plastic hinges ("Moment M3" elements). On the beams, hinges are at the end of haunched connection, namely at a distance $\mathrm{sh}$, from the face of the column; while on the columns they are assigned with a relative distance of 0 and 1 . Of fundamental importance are the demand for plastic rotation during the development of the kinematic mechanism and the capacity for plastic rotation. In the case of columns with dimensionless normal stress lower than 0.30 and beams in flexure, the plastic deformation capacity is expressed as a multiple of the chord rotation at yielding $\vartheta$, defined as a property of the member itself.

In particular, for columns arranged strong axis and for beams, the rotation of the member is:

$$
\theta_{y}=\frac{\gamma_{r m} M_{p l . y} l_{m}}{6 E I_{m}}
$$

For columns arranged weak axis, the rotation of the member is:

$$
\theta_{z}=\frac{\gamma_{r m} M_{p l . z} l_{m}}{6 E I_{m}}
$$

where $\mathrm{M}_{\text {pl.y }}$ and $\mathrm{M}_{\mathrm{pl.z}}$ are the plastic moment of the member for $\mathrm{y}$ and $\mathrm{z}$ axis respectively; $\mathrm{l}_{\mathrm{m}}$ is the length of the member; $I_{m}$ is the moment of inertia; $E$ is the elastic modulus and $\gamma_{\mathrm{rm}}$ is the material overstrength coefficient place equal to 1.25 . Plastic rotation capacity at the end of 
beams or columns with dimensionless axial load $v$ not greater than 0.30 in Table B. 1 of EC8-3 [67] are reported, as shown in Figure 6. The hysteresis type is kinematic.

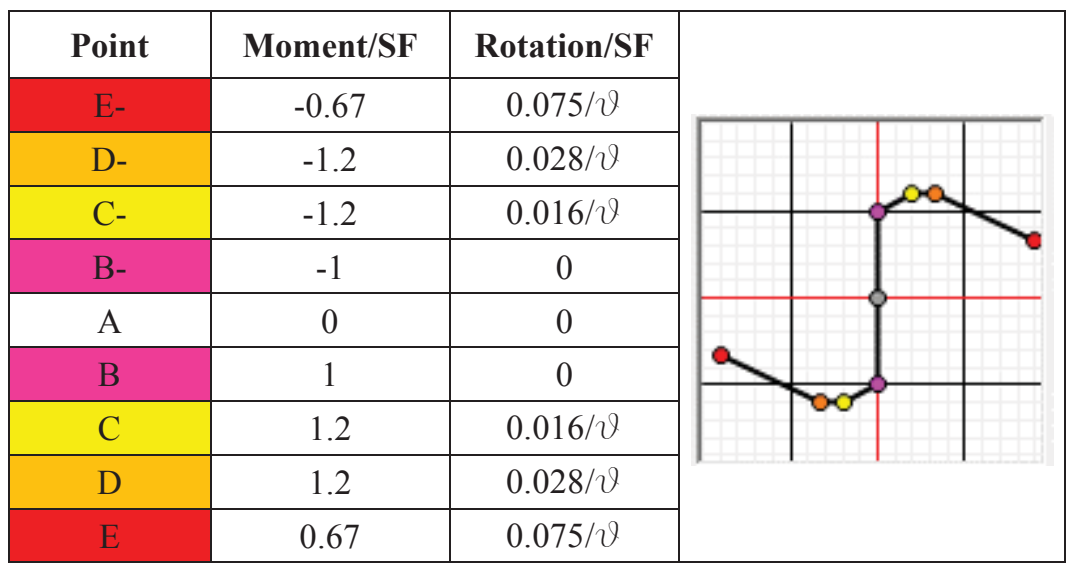

Table 6: Beams and columns hinge model.

To model the plastic hinge of the bracing diagonals in Sap2000 we start from the Georgescu model [68] generally used for cyclic analysis (Figure 9) [67].

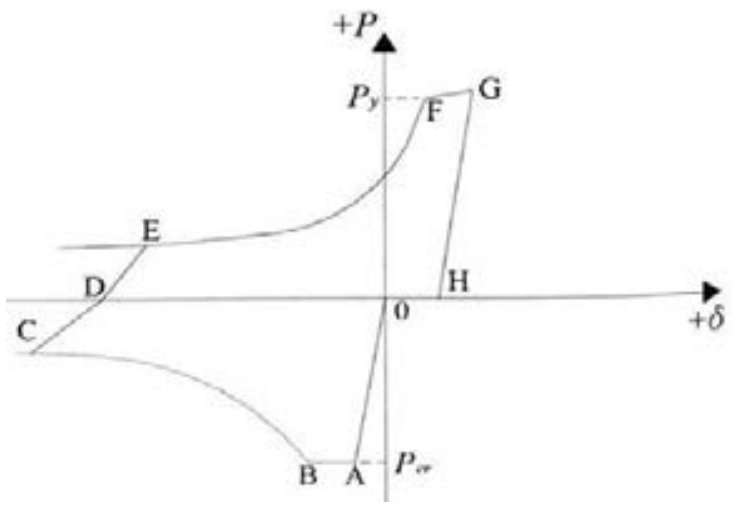

Figure 9: Georgescu model for cyclic analysis

The model used for the pushover analyzes starts from a first simplification of the Georgescu model (Figure 10) that exploits the OA, AB and BC traits for compression. On the other hand, in traction the behavior is defined with a Perfectly Plastic Elastic bound (EPP).

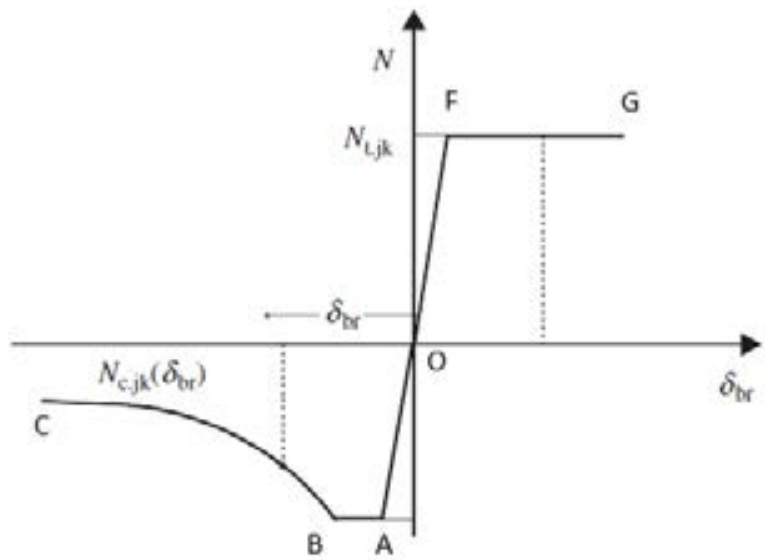

Figure 10: First simplification of the Georgescu model for pushover analysis 
The equations of model branches are reported in the following:

- Initial imperfection

$$
f_{0}=\frac{W}{A} \alpha\left(\overline{\lambda^{2}}-0.04\right) \text { with } \alpha=0.21, \bar{\lambda}=\frac{\lambda}{\lambda_{y}}
$$

- OA branch:

$$
P=\frac{E A}{L} \delta_{O A}=K_{d} \delta_{O A} \quad \text { with } P \text { limited to } P_{\text {crit }} ; \quad \delta_{A}=\frac{P_{\text {crit }}}{K_{d}}
$$

- $\mathrm{AB}$ branch:

$$
\begin{gathered}
f_{t B}=\frac{M_{p l}}{P_{c r i t}}\left(1-\frac{P_{c r i t}}{P_{y}}\right) \\
\delta_{B}=-\frac{P_{c r i t} L}{E A}+\frac{\pi^{2}}{4 L}\left(f_{t B}^{2}-f_{0}^{2}\right)
\end{gathered}
$$

- BC branch:

$$
\begin{gathered}
f_{t}=\frac{M_{p l}}{P}\left(1-\frac{P}{P_{y}}\right) \text { with } P \text { generic }<P_{\text {crit }} \\
f_{0}=\delta_{B C}=-\frac{P L}{E A}+\frac{\pi^{2}}{4 L}\left(f_{t}{ }^{2}-f_{0}{ }^{2}\right)
\end{gathered}
$$

- OF branch:

$$
P=\frac{E A}{L} \delta_{O F}=K_{d} \delta_{O F} \quad \text { with } P \text { limited to } P_{y} ; \quad \delta_{F}=\frac{P_{y}}{K_{d}}
$$

- FG branch:

$$
P=P_{y} \quad \forall \delta_{F G}
$$

A second simplification adopted in the Sap2000 model consist in considering the OA and OF sections as rigid, while the $\mathrm{BC}$ section is represented with bilinear approximation (Figure 11). The elastic behaviour is demanded to the beam-column element representing the diagonal section.

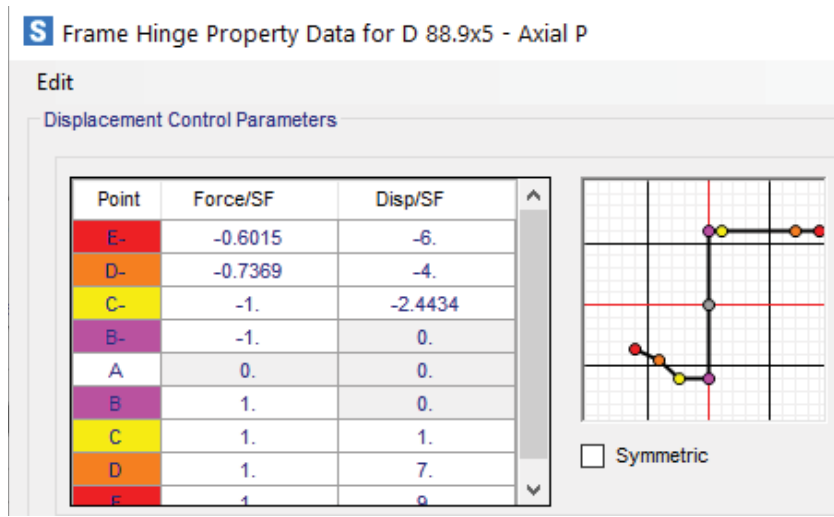

Figure 11: Second simplification of the Georgescu model for pushover analysis, in Sap2000

The bilinear approximation of the BC section was obtained by considering two points of the curve, or those corresponding to the limit displacements provided by Eurocode for the compressed diagonals. These points were also identified in traction (on the horizontal branch) according to the limits given for taut diagonals. 
For braces in compression the inelastic deformation capacity should be expressed in terms of the axial deformation of the brace, as a multiple of the axial deformation of the brace at buckling load, $\Delta_{c}$. For braces in compression (except for braces of eccentric braced frames) the inelastic deformation capacities at the three LSs may be taken in accordance with Table B.2 of EC8-3 [67]. For braces in tension the inelastic deformation capacity should be expressed in terms of the axial deformation of the brace, as a multiple of the axial deformation of the brace at tensile yielding load, $\Delta_{t}$. For braces in tension (except for braces of eccentric braced frames) with cross section class 1 or 2 , the inelastic deformation capacities at the three LSs may be taken in accordance with Table B.3 in EC8-3 [67]. To allow the diagonal buckling and therefore, their cyclic behaviour the diagonal must be split into two parts and the middle node must be put out of plane with an initial imperfection.

\subsection{Structures with FREEDAM joints}

In the structures with FREEDAM connections the beams and columns have the same plastic hinge described above. The P-hinge properties representing the FREEDAM connections are rigid perfectly plastic, and they are located at the column face, i.e. where it is expected the device rotation. The rotation depends on the level arm of the device used. Under the bending action, the node is forced to rotate around the center of rotation, located at the base of the upper T-stub, and the dissipated energy is guaranteed by the alternating sliding of the bolts on the vertical stainless-steel plate (Figure 12).

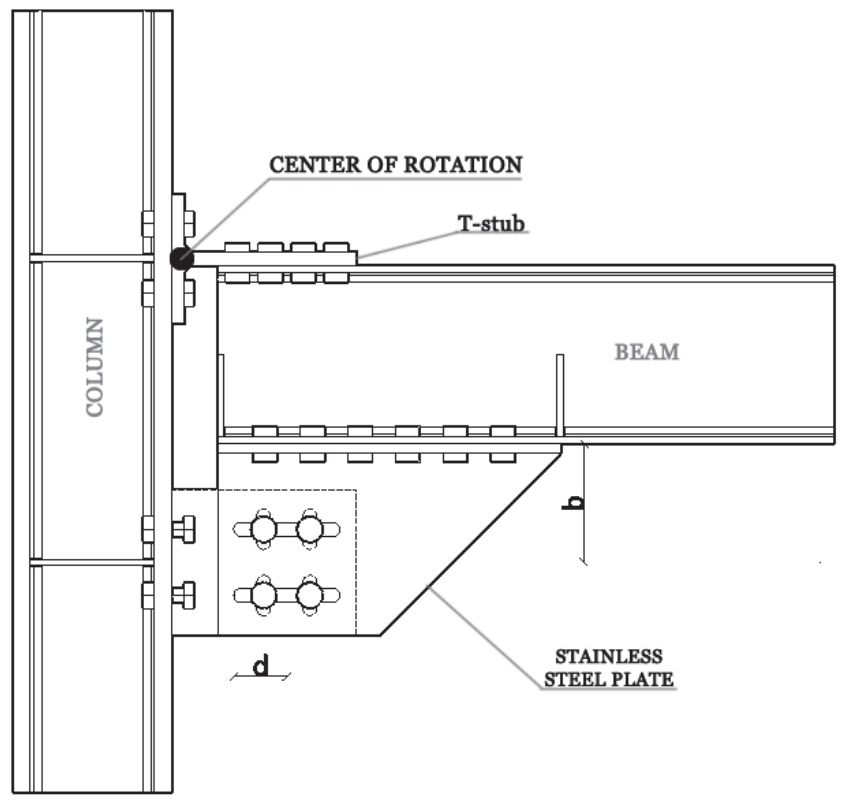

Figure 12: Center of rotation of FREEDAM hinge

In particular, the FREEDAM rotation is:

$$
\vartheta_{y}=\frac{d}{H} \text { with } H=h_{b}+b
$$

where $\mathrm{d}$ is the distance between the bolt and the slot, $h_{b}$ is the beam height, $b$ is the distance between the center of gravity of the bolts and the lower flange of the beam.

As already mentioned, the bracing diagonals of the D-CBFs structures equipped with FREEDAM dampers do not suffer any damage in the case of a seismic event as the energy dissipation occurs through the friction dampers placed at the chevron braces intersection. 


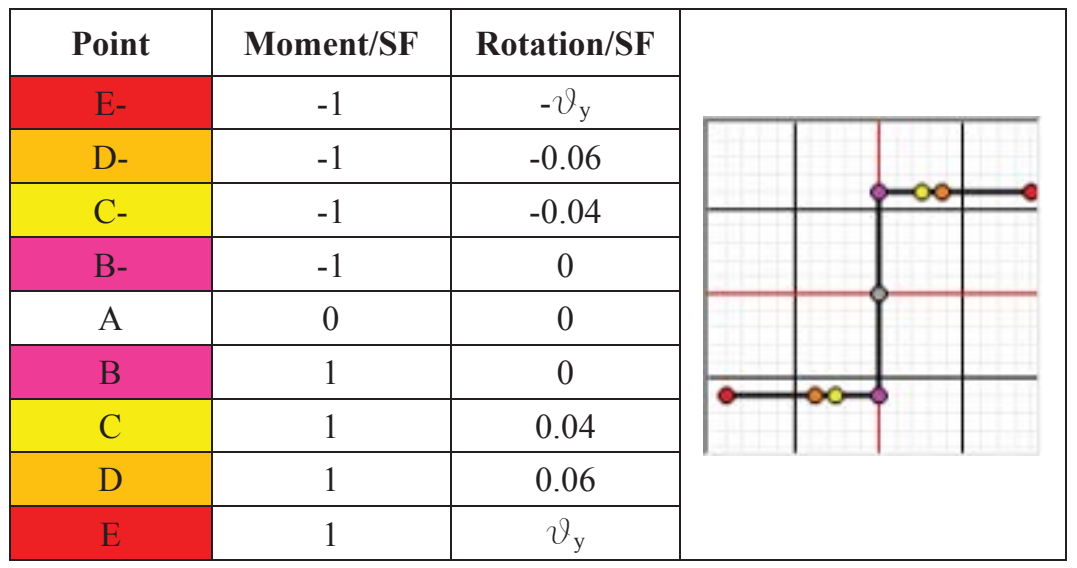

Table 7: FREEDAM hinges model.

For the sole purpose of carrying out pushover and non-linear dynamic analyses, this friction device was modeled as a "short link" with a cross-section equal to the diagonals it joins and a cross section axial area of zero. The length of the link is: $1_{\text {link }}=h_{b} / 2+260$; in other words, it has been set equal to half the height of the beam plus the height of device D1.
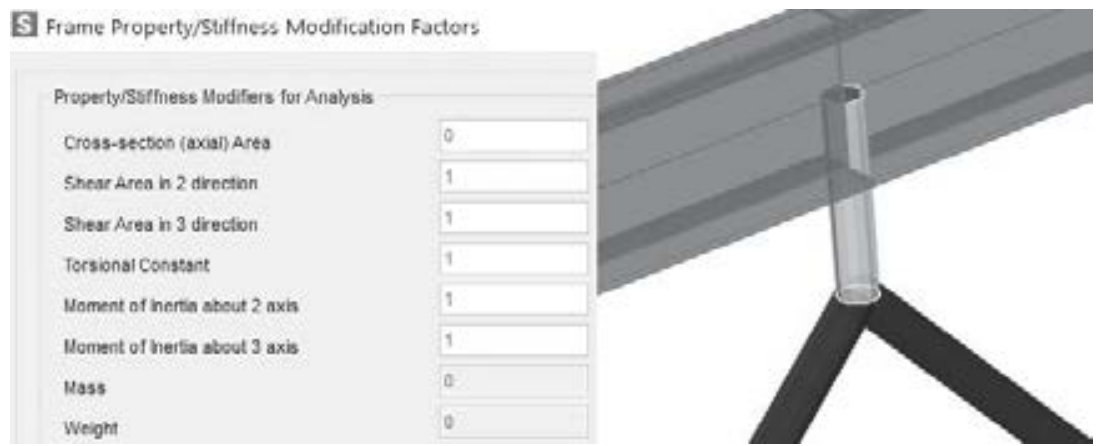

Figure 13 - Friction dampers model for pushover and non-linear dynamic analyses

A rigid plastic frame hinge "Shear V2" behaviour is assigned to "link" members with a max displacement equal to: $d_{\max }=0.04 \cdot h_{i}=0.04 \cdot 3.50=0.14 \mathrm{~m}$; where $h_{i}$ is the inter-storey height of the structure. In the definition of FREEDAM hinges, the bending and shear strength of the beam-column and diagonal intersection devices was amplified with the coefficient $\gamma_{\mathrm{rm}}$ equal to $1.6[52]$.

\begin{tabular}{|c|c|c|c|c|}
\hline Point & Moment/SF & Rotation/SF & & \\
\hline E- & -1 & $-\mathrm{d}_{\max }$ & & \\
\hline D- & -1 & -0.07 & & \\
\hline C- & -1 & -0.04 & $\because 0$ & \\
\hline B- & -1 & 0 & & \\
\hline A & 0 & 0 & & \\
\hline B & 1 & 0 & & \\
\hline $\mathrm{C}$ & 1 & 0.04 & & \\
\hline $\mathrm{D}$ & 1 & 0.07 & & \\
\hline E & 1 & $\mathrm{~d}_{\max }$ & & \\
\hline
\end{tabular}

Table 8: - FREEDAM hinges "Shear V2" model 


\section{PUSHOVER ANALYSES}

Pushover analyses are led in displacement control considering both geometrical and mechanical nonlinearities under two lateral load patterns, as suggested by EC8: a load distribution corresponding to the fundamental mode shape and a uniform distribution proportional to seismic masses at each floor. The response parameters monitored by the performed pushover analyses are illustrated in Figure 14. Pushover analyses are carried out on SAP2000 computer program.

In particular, $V_{u}$ is the base shear at maximum plastic capacity of the structure, $V_{1}$ is the base shear at first plastic event; $\delta_{1}$ and $\delta_{\max }$ are the roof displacements corresponding to the formation of the first plastic hinge and to the first occurrence of the structural collapse corresponding to the achievement of the ultimate rotation.

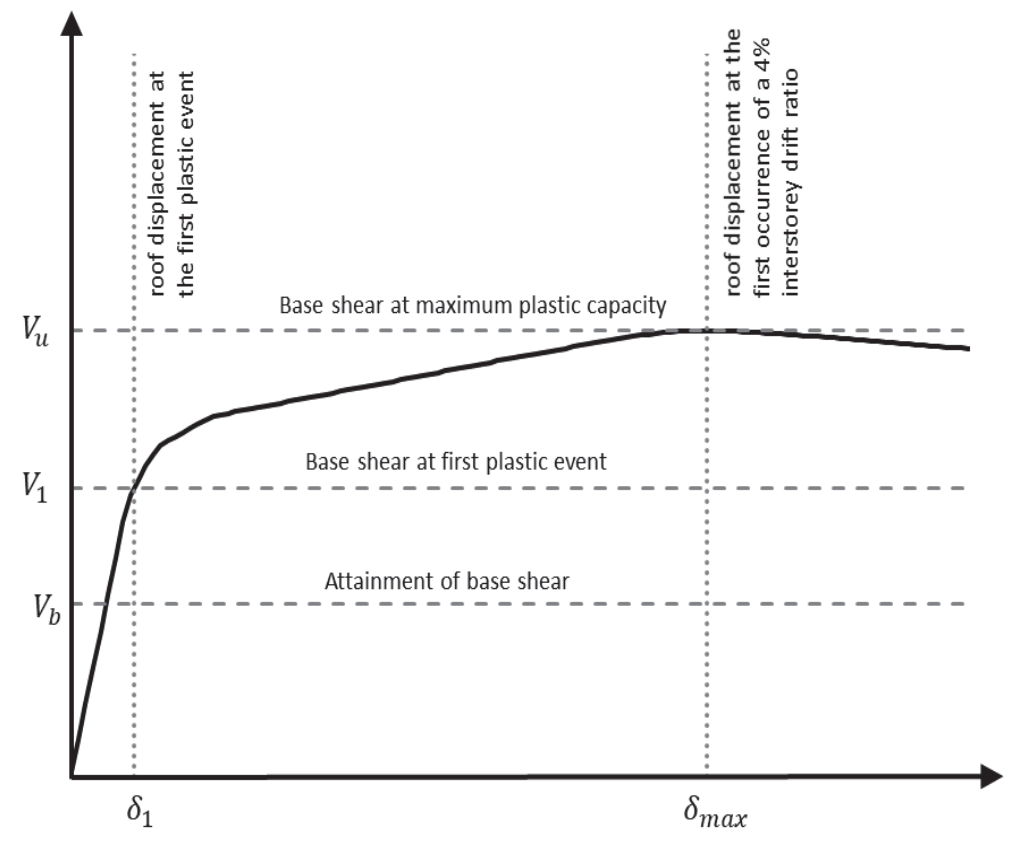

Figure 14: Monitored parameters in capacity curves.

Among the strength parameters monitored the base shear $V$, is a measure of the overall overstrength of the structure. In addition, the ratio $V_{u} / V_{1}$, is a measure of redundancy. This value depends on the frame configuration, formation of the collapse mechanism, redistribution capacity and gravity loading. Conversely, $V_{1}$ can be considered as an overdesign factor related to aspects of the design procedure such as differences between actual and nominal material strength, member oversizing due to choices of commercial cross section and design governed by deformation and/or non-seismic loading. The $\mu$ factor is defined as:

$$
\mu=\frac{\delta_{\max }}{\delta_{1}}
$$

where $\delta_{\max }$ is the roof displacement at structural collapse and $\delta_{1}$ is the roof displacement associated to formation of the first plastic hinge. From the comparison of pushover response curves (from Figure 15 to Figure 18) it is observed that the D-CBF designed according to EC8 are characterized by larger overstrength than the corresponding structures designed according to TPMC. Moreover, EC8 rules induce overdesigning the braces to satisfy both slenderness limits and the variation of brace overstrength along the building height, while TPMC do not have such requirements. In general, the differences among the different "haunched" connections are negligible. 


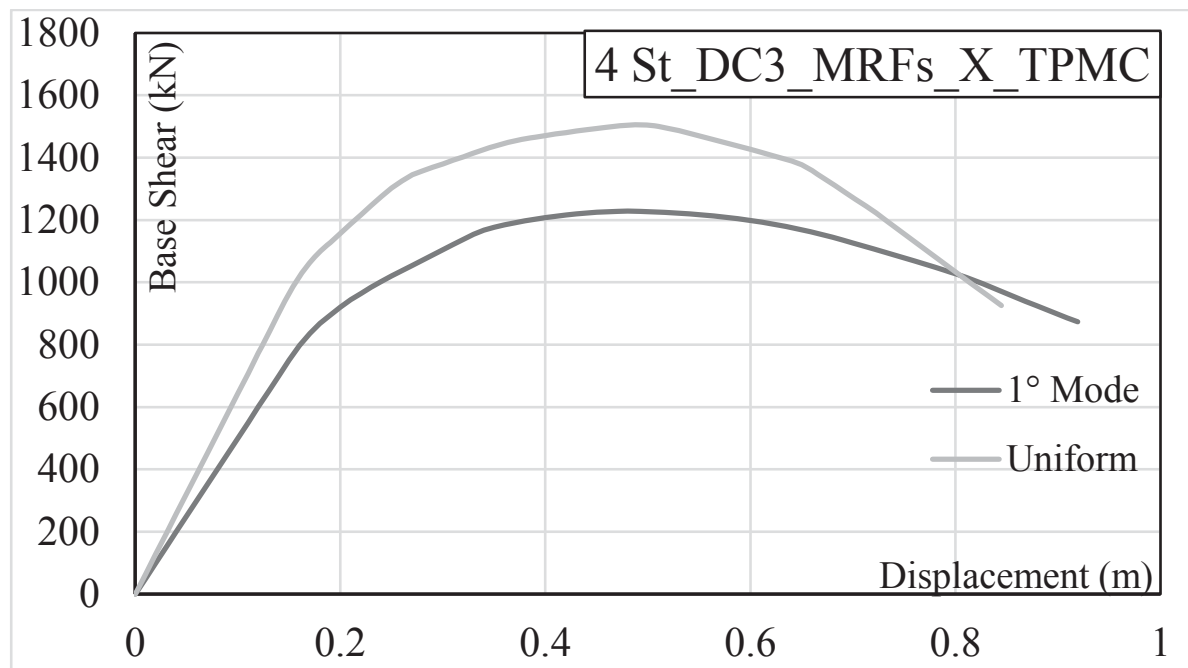

Figure 15: Push-over curves for 4 Storey MRFs with traditional connections

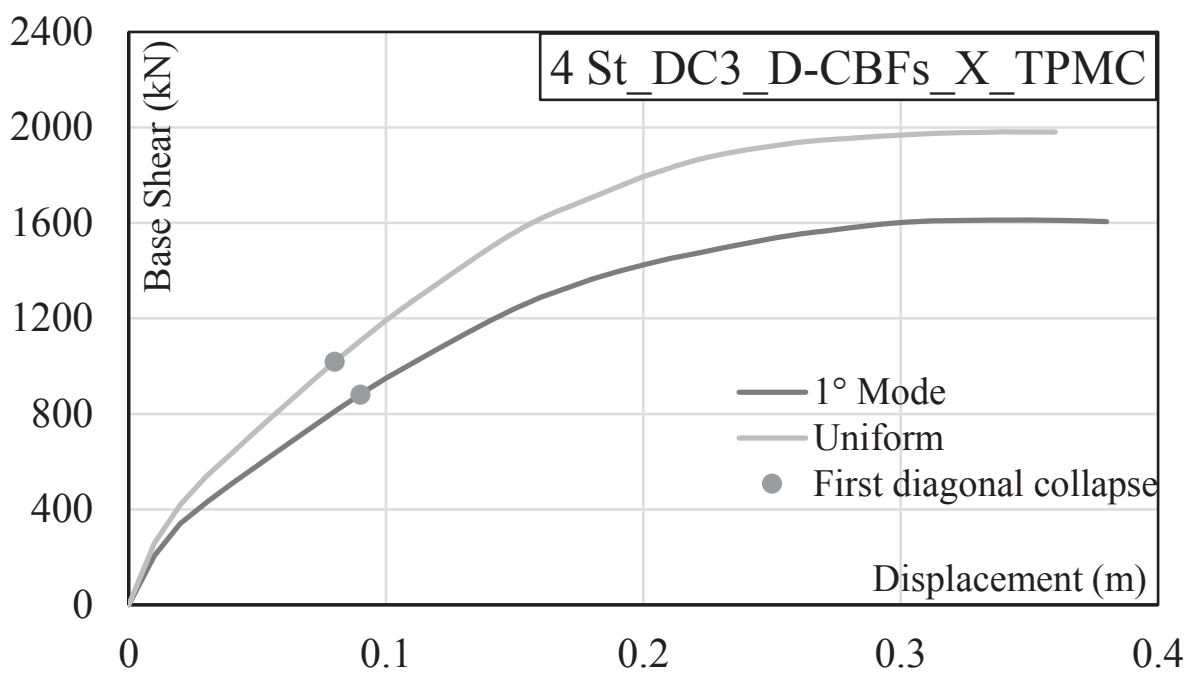

Figure 16: Push-over curves for 4 Storey D-CBFs with traditional connections

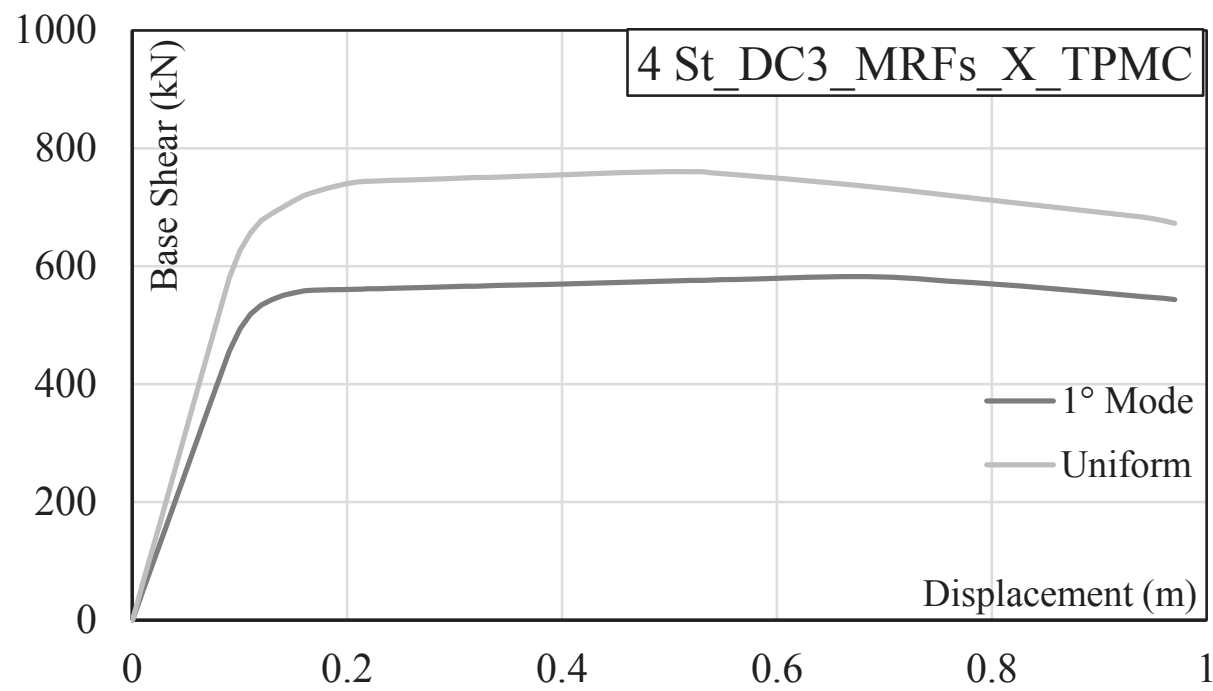

Figure 17: Push-over curves for 4 Storey MRFs with FREEDAM connections 


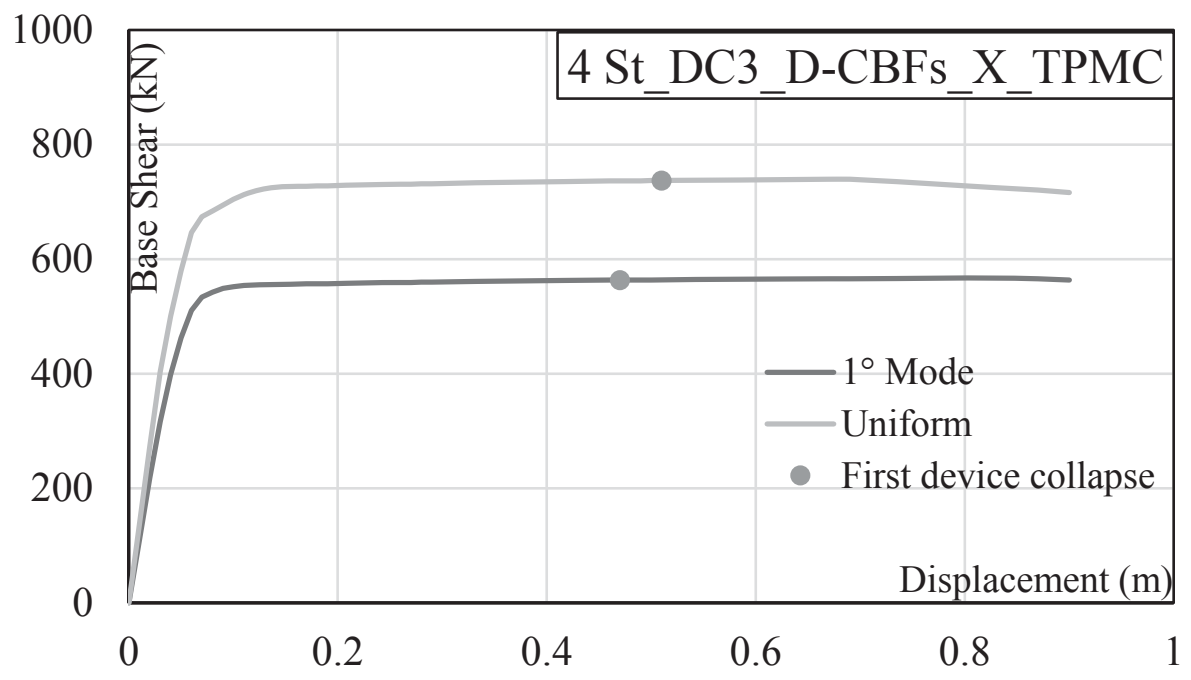

Figure 18: Push-over curves for 4 Storey D-CBFs with FREEDAM connections

In Figure 19 and Figure 21 the redundancy and the ductility of the structures are reported, respectively. It is observed that the highest values of redundancy and ductility are exhibited by the structures designed by EC8. The presence of the "haunched" connections seems to affect not too much the seismic performances of the structures while the effect of balanced panel zone is easy pointed out because of higher values of the ductility.

About global ductility (Figure 19-Figure 20), it can be noted that the MRFs_FREEDAM and D-CBFs_FREEDAM structures have a higher ductility if compared with structures equipped with traditional joints.

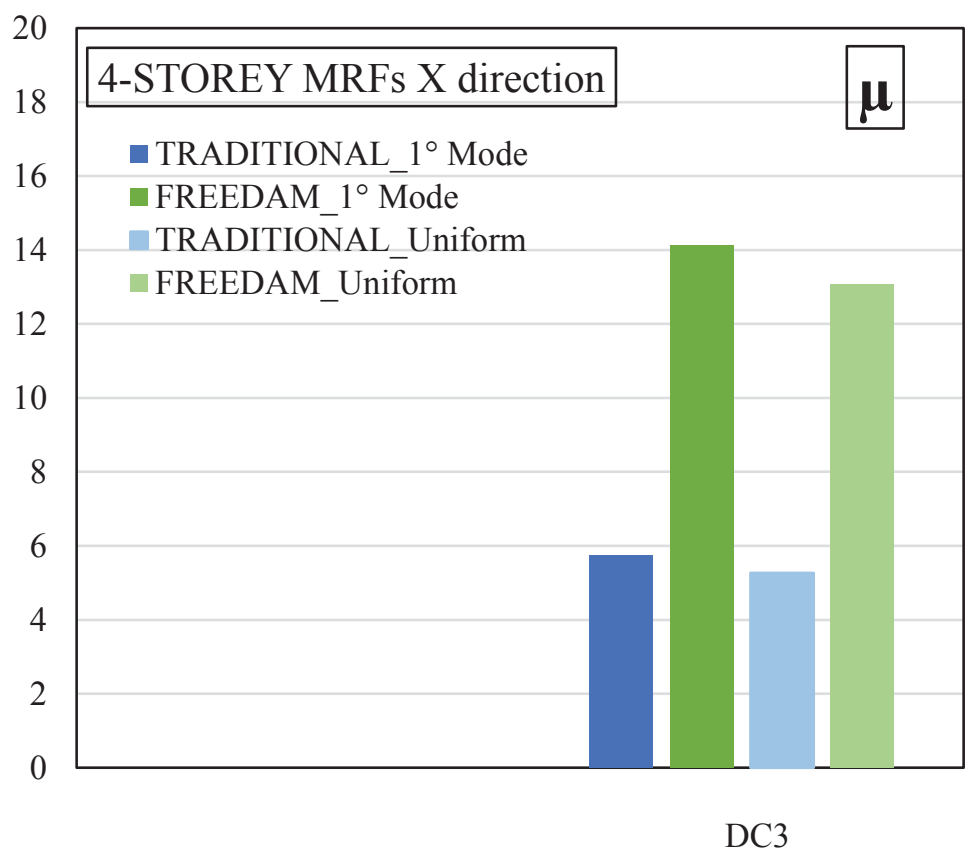

Figure 19: Ductility for MRFs with traditional and FREEDAM connections 


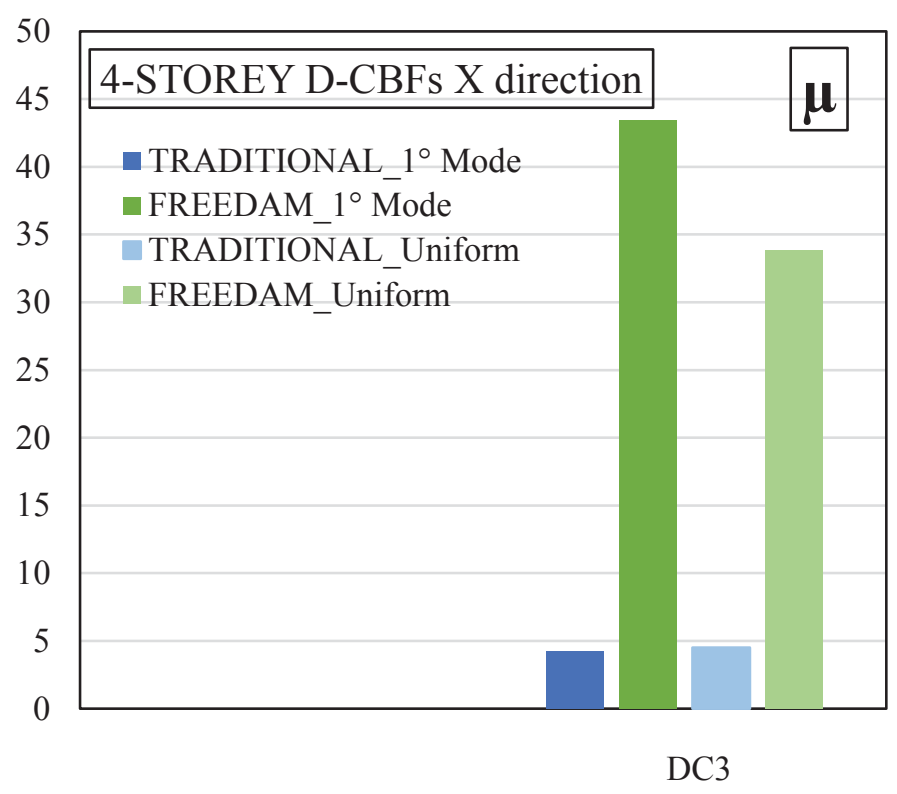

Figure 20: Ductility for D-CBFs with traditional and FREEDAM connections

About the system overstrength (Figure 21-Figure 22), it can be observed that in traditional structures it is higher than the FREEDAM ones. However, this redundancy is higher than the one suggested by the new Eurocode draft [59].

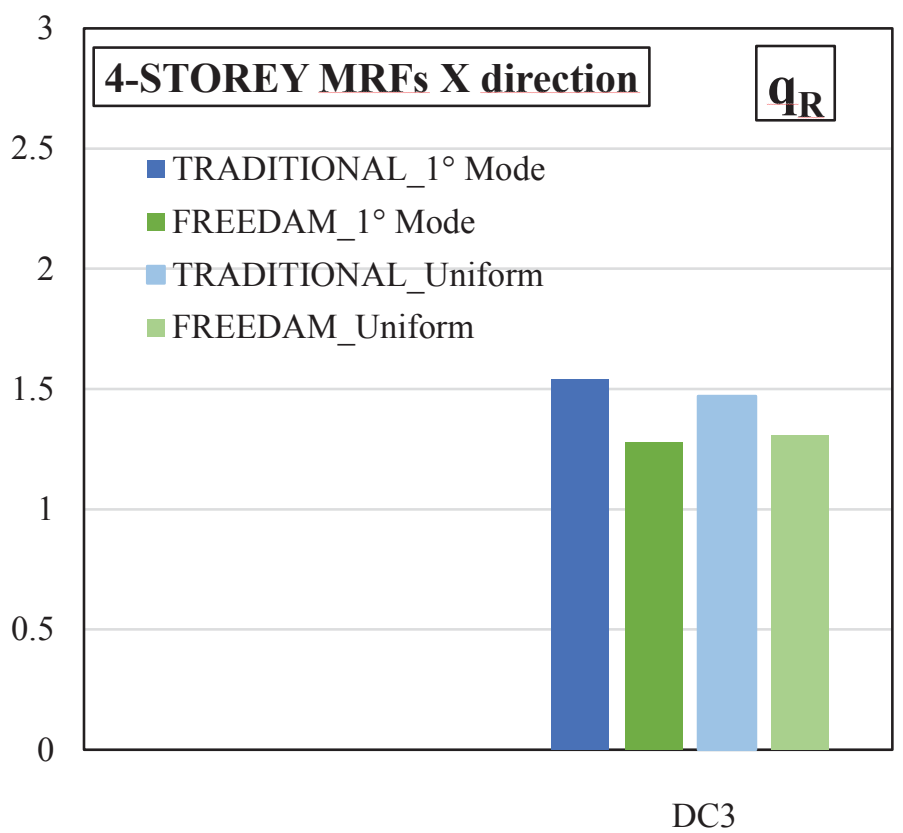

Figure 21: Redundancy for MRFs with traditional and FREEDAM connections 


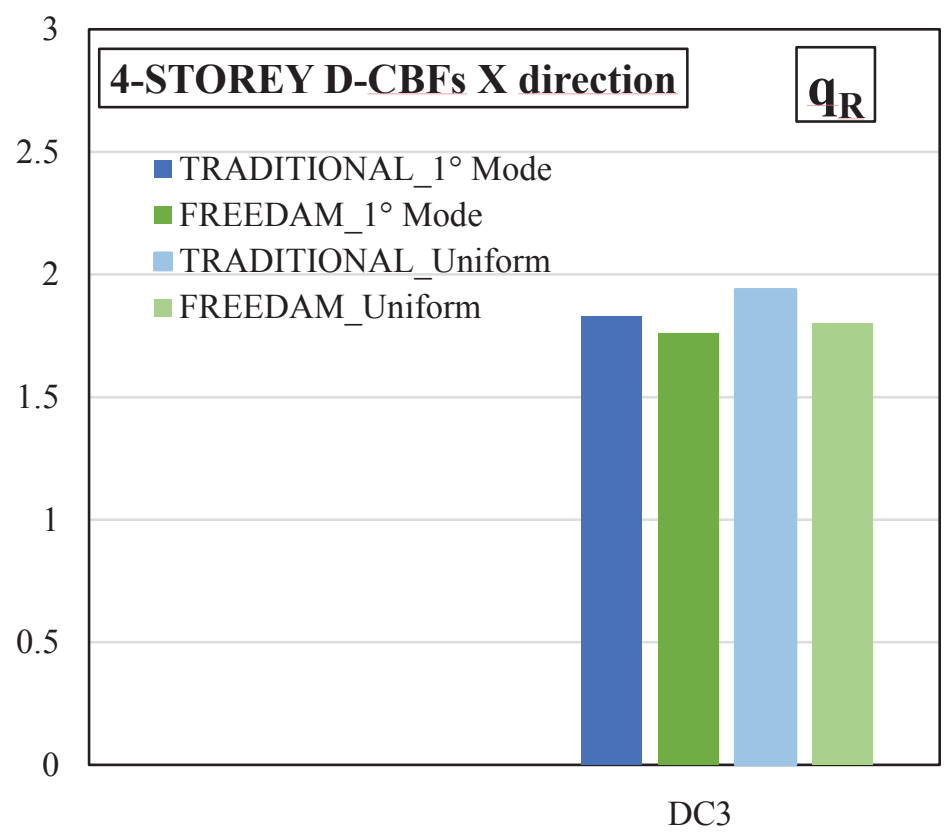

Figure 22: Redundancy for D-CBFs with traditional and FREEDAM connections

\section{DYNAMIC NON-LINEAR ANALYSES}

Non-linear Dynamic Analyses [69] are also performed to investigate the structural performance for the 3 limit states defined in EN1998-3 [67], namely damage limitation (DL), significant damage (SD) and collapse prevention (CP). EN1998-3 [67] associates a seismic intensity with each limit states and establishes performance limits related to global and local damage. The IDA analyses have been carried out for three increasing values of PGA value corresponding to the following limit state Damage limitation (DL), Severe Damage (SD) and Near Collapse (NC). The values of the multiplier of accelerograms are assumed equal to 0.59 , 1 and 1.73 for DL, SD and NC [67], respectively. The non-linear dynamic analyses are carried out using the same structural model adopted for pushover analyses. Rayleigh formulation for a 5\% damping has been assumed with the proportional factors computed with reference to the first and second mode of vibration. In addition, first $T_{1}$ and second $T_{2}$ periods of vibration are required and reported in Table 10. Record-to-record variability has been accounted for by considering 10 recorded accelerograms selected from ESM [70]. In Table 9 the analyzed records (Earthquake name, Date, Duration, Station name, Station Country, moment magnitude (MW), local magnitude (ML) and Fault mechanism) have been reported.

\begin{tabular}{cccccc}
\hline $\begin{array}{c}\text { Station } \\
\text { Code }\end{array}$ & Station Name & Earthquake name & Date & Network & Mw \\
\hline BAR & Bar-Skupstina & NW_Balkan_Peninsula & 15.04 .1979 & EU & 6.9 \\
CSO1 & CARSOLI1 & L'Aquila & 06.04 .2009 & IT & 6.1 \\
KAL1 & KAL1 & Southern_Greece & 13.09 .1986 & HI & 5.9 \\
MCT & Macerata & Central_Italy & 26.10 .2016 & IT & 5.9 \\
MZ12 & Amatrice & Central_Italy & 26.10 .2016 & 3 A & 5.9 \\
MZ102 & Accumoli & Central_Italy & 30.10 .2016 & 3A & 6.5
\end{tabular}


Table 9: Analized ground motion records

These recorded accelerograms have been selected to approximately match the code elastic response spectrum [58]. In other words, the spectra of the 7 recorded accelerograms have been properly scaled to let their average value to be compatible with the design EC8 spectrum. The accelerogram multipliers are reported in the Table 11.

\begin{tabular}{ccc}
\hline \multirow{2}{*}{ Scheme } & \multicolumn{2}{c}{ TPMC } \\
\cline { 2 - 3 } & $\mathbf{T}_{\mathbf{1}}(\mathbf{s})$ & $\mathbf{T}_{\mathbf{2}} \mathbf{( s )}$ \\
\hline MRFs_TRADITIONAL & 1.62 & 0.48 \\
\hline MRFs_FREEDAM & 1.63 & 0.52 \\
\hline MRFs_TRADITIONAL & 0.84 & 0.27 \\
\hline MRFs_FREEDAM & 0.77 & 0.27 \\
\hline
\end{tabular}

Table 10: First and second vibration periods

\begin{tabular}{cccc}
\hline Station Code & $\begin{array}{c}\text { Length } \\
\text { (s) }\end{array}$ & $\begin{array}{c}\text { Step recording } \\
\text { (s) }\end{array}$ & $\begin{array}{c}\text { Scale Factor } \\
(-)\end{array}$ \\
\hline BAR & 47.83 & 0.01 & 1.11 \\
CSO1 & 99.80 & 0.01 & 11.7 \\
KAL1 & 30.02 & 0.01 & 1.3 \\
MCT & 96.38 & 0.01 & 5.85 \\
MZ12 & 82.67 & 0.01 & 3.64 \\
MZ102 & 77.15 & 0.01 & 1.04 \\
PZ11 & 63.45 & 0.01 & 9.75 \\
\hline
\end{tabular}

Table 11: Accelerogram multipliers, length and step recording

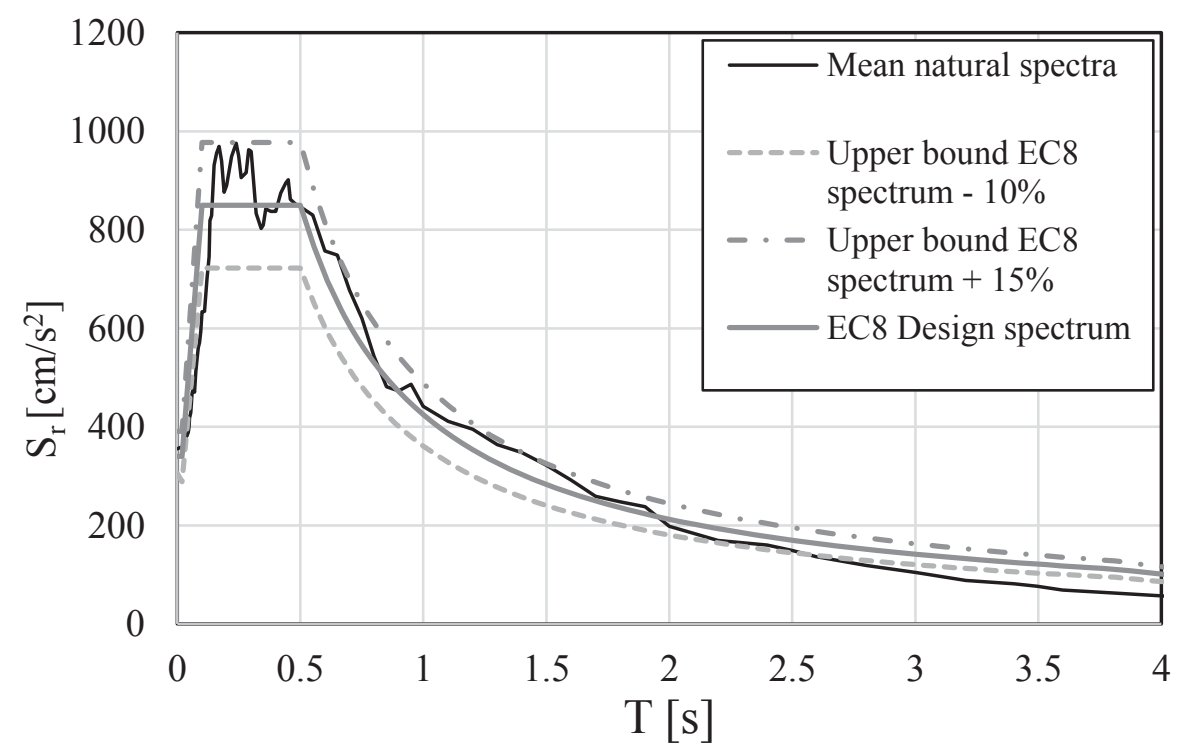

Figure 23: Comparison between natural signals average spectrum and EC8 design spectrum 
From dynamic analyses it can be observed that the soft-storey mechanism does not develop, but the collapse mechanism is almost global, i.e. it develops a pattern of hinge compatible with the global mechanism.

From a comparison between the seismic performance of the structures with traditional connections and the same structures equipped with FREEDAM connections given in terms of Maximum Interstorey Drift, it is possible to observe that the structure equipped with FREEDAM connections at beam-to-column joint show, on average, better performances if compared with full strength joint ones. It is due to the high dissipative capacity of FREEDAM connections which do not present relevant degradation under cyclic loading. In addition, it is important observing that the performances of the structures equipped with FREEDAM connections can be higher if the involvement of bolt in shear is considered after the achievement of the ultimate stoke of dampers. However, the maximum stroke is never achieved even at Near Collapse limit state. The average maximum absolute peak interstorey drift of FREEDAM structures is lower than the structures with traditional full-strength joints for MRFs. In particular this happens for increasing values of PGA corresponding to the multipliers 1 and 1.5. Conversely, for the D-CBFs structures the opposite occurs, this is probably due to the insertion of the friction device at the top of chevron braces which guarantees a maximum displacement that can be reached of $14 \mathrm{~cm}$. In Figure 24 and Figure 25 the comparison between MRFs and D-CBFs in terms of peak interstorey drift for each limit state is reported.
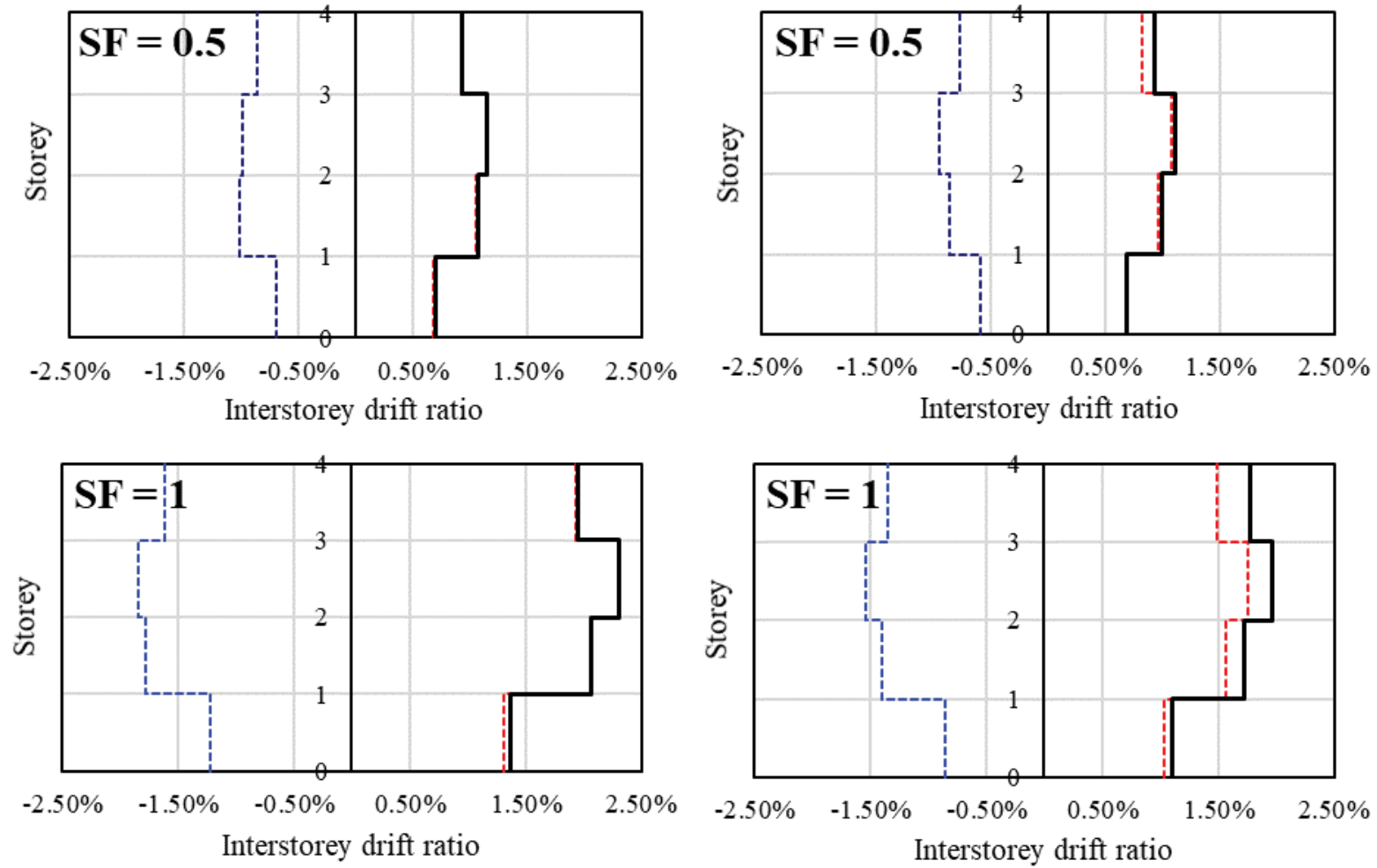


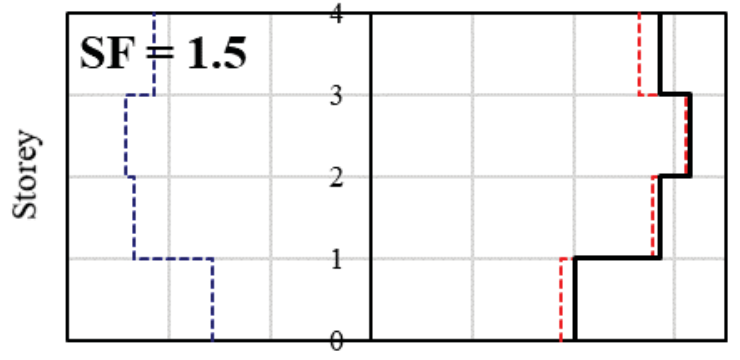

$-3.00 \%-2.00 \%-1.00 \% \quad 0.00 \% \quad 1.00 \% \quad 2.00 \% \quad 3.00 \%$ Interstorey drift ratio

AVG MAX

(a)

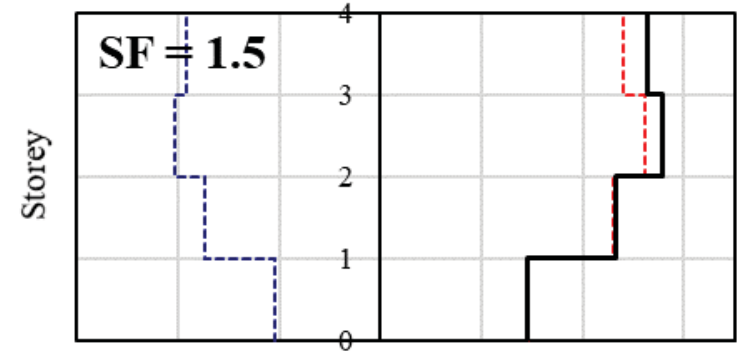

$-3.00 \%-2.00 \%-1.00 \% \quad 0.00 \% \quad 1.00 \% \quad 2.00 \% \quad 3.00 \%$ Interstorey drift ratio

AVG MAX

(b)

Figure 24: Peak interstorey drift curves for MRFs equipped with both traditional haunched connections and FREEDAM connections
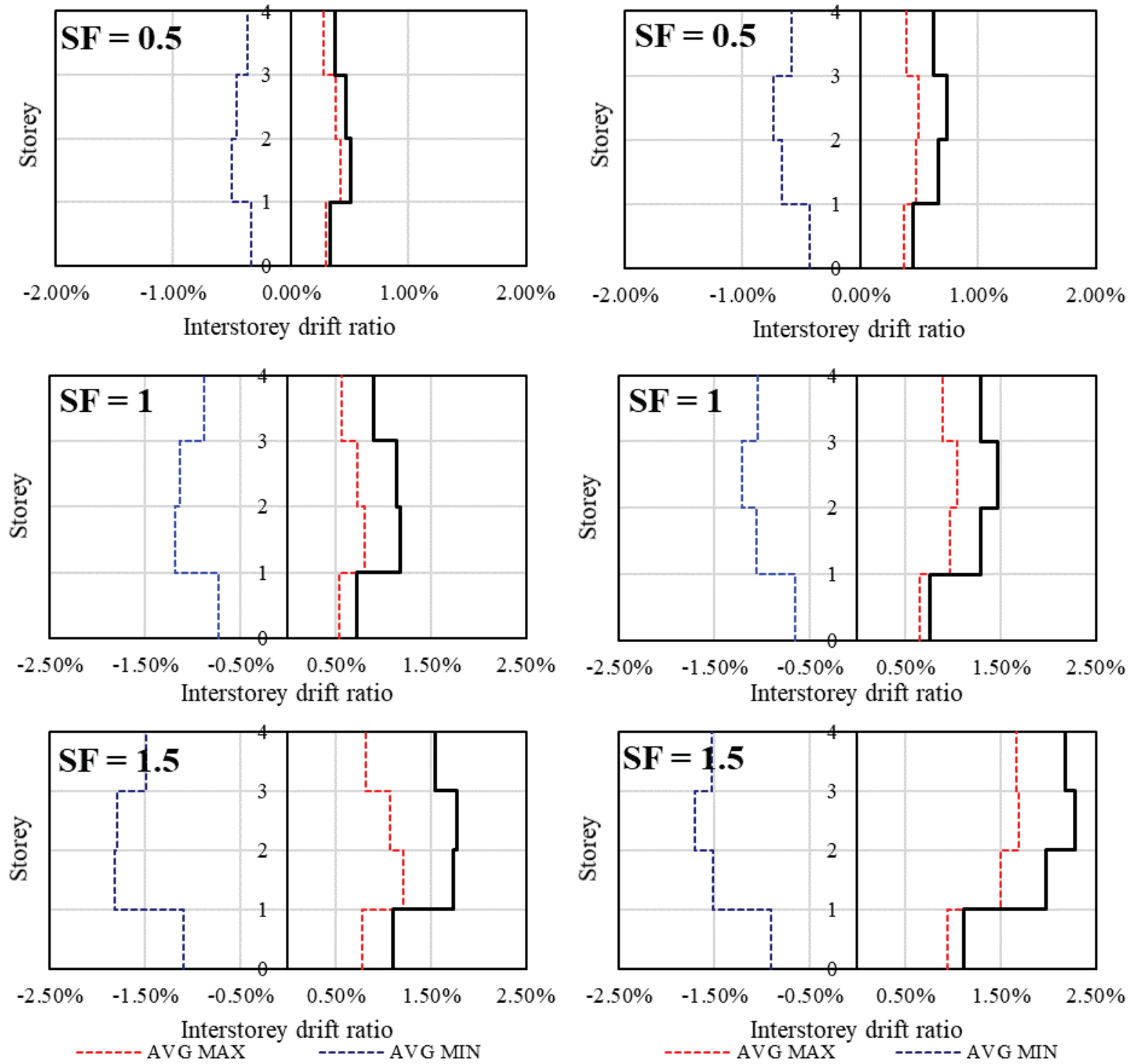

(a)

(b)

Figure 25: Peak interstorey drift curves for D-CBFs equipped with both traditional haunched connections (a) and FREEDAM connections (b) 


\section{AKNOWLEDGEMENTS}

The research leading to the results presented in this paper has received funding from the European Union's Research Fund for Coal and Steel (RFCS) research program under grant agreement $n^{\circ}$ RFCS-AM-2019-899321. The support of the European Commission within RFCS Research \& Innovation is gratefully acknowledged.

\section{CONCLUSIONS}

- The work herein presented, developed in the contest of the RFCS Project FREEDAM Plus.

- Both Dual CBFs and MRFs low rise structures are designed considering traditional connections and FREEDAM connections.

- The design methodology adopted is the Theory of Plastic Mechanism Control (TPMC).

- The comparison in terms of weight among MRFs and D-CBFs equipped with haunched and FREEDAM connections shows that in both cases the use of traditional connections leads to heavier structures.

- From the pushover it is observed that the redundancy is higher for the structure with traditional connections

- Conversely, the ductility is higher for the structures equipped with FREEDAM connections.

- Form the Dynamic Analysis point of view it is possible to observe that structures equipped with FREEDAM connections have better seismic performance than structures equipped with traditional connections.

- The TPMC has proved to be an excellent design tool for both traditional and FREEDAM structures assuring that columns sections are not involved in plastic range.

\section{REFERENCES}

[1] S. Avgerinou, X. Lignos, P. Thanopoulos, A. Spiliopoulos, I. Vayas, "Momentresisting-frames under cyclic loading: Large scale tests and validation of plasticity and damage numerical models", Soil Dynamics and Earthquake Engineering, 115, pp. 564577, (2018).

[2] C. Bernuzzi, D. Rodigari, M. Simoncelli, "Incremental dynamic analysis for assessing the seismic performance of moment resisting steel frames" (2020) Ingegneria Sismica, (4), pp. 23-44.

[3] A. Sandoli, B. Calderoni, G. Brandonisio, Effect of panel zone on non-linear behaviour of mrfs in the light of seismic codes (2019) Ingegneria Sismica, 36 (4), pp. 100-119.

[4] C. Bernuzzi, C. Chesi, D. Rodigari, R. De Col, "Remarks on the approaches for seismic design of moment-resisting steel frames", Ingegneria Sismica, 35 (2), pp. 37-47. (2018).

[5] R. Montuori, E. Nastri, P. Todisco, "Influence of the seismic shear proportioning factor on steel MRFs seismic performances", Soil Dynamics and Earthquake Engineering, 2020, 106498, ISSN 0267-7261, https://doi.org/10.1016/j.soildyn.2020.106498. 
[6] V. Piluso, R. Montuori, E. Nastri, A. Paciello, "Seismic response of MRF-CBF dual systems equipped with low damage friction connections" Journal of Constructional Steel Research, 154, pp. 263-277, (2019).

[7] S. Streppone, R. Montuori, "Design and Seismic Assessment of MRFs and DUAL CBFs equipped with friction dampers", Compdyn 2019, 7th International Conference on Computational Methods in Structural Dynamics and Earthquake Engineering, 24-26 June 2019.

[8] B.V. Fell, A.T. Myers, G.G. Deierlein, and A.M. Kanvinde, A. "Testing and simulation in steel braces", Paper presented at the 8th U.S. national conference on EarthquakeEngineering, San Francisco, CA. (2006, April).

[9] K. Ikeda, S.A. Mahin, "A refined physical theory model for predicting the seismic behaviour of braced frames" (Report UMEE 77R3). MI: Department of Civil Engineering, University of Michigan, (1984).

[10] A.K. Jain, S.C. Goel, R.D. Hanson, "Hysteresis behaviour of bracing members and seismic response of braced frames with different proportions" (Report UMEE 78R3). Ann Arbor, MI: Department of Civil Engineering, University of Michigan, (1978).

[11] K. Lee, M. Bruneau, "Review of energy dissipation compression members in concentrically braced frames" (Report MCEER-02-0005). Buffalo, NY: Department of Civil Engineering, The University of Buffalo. (2002).

[12] R. Sabelli, S. Mahin, C. Chang, "Seismic demands on steel braced frame buildings with buckling-restrained braces”, Engineering Structures, 25, 655-666. (2003).

[13] X. Tang, S.C. Goel, "Brace fractures and analysis of phase I structure" ASCE Journal of Structural Engineering, 102, 1960-1976. (1989).

[14] R. Tremblay, "Inelastic seismic response of steel bracing members", Journal of Constructional Steel Research, 58, 665-701. (2002).

[15] L. Fiorino, V. Macillo, R. Landolfo, "Shake table tests of a full-scale two-story sheathing-braced cold-formed steel building" Engineering Structures, 151, pp. 633-647, (2017).

[16] L. Fiorino, M.T. Terracciano, R. Landolfo, "Experimental investigation of seismic behaviour of low dissipative CFS strap-braced stud walls" Journal of Constructional Steel Research, Vol. 127, pp. 92-107, (2016).

[17] V. Macillo, L. Fiorino, R. Landolfo, "Seismic response of CFS shear walls sheathed with nailed gypsum panels: Experimental tests" Thin-Walled Structures, Vol. 120, pp. 161-171, (2017).

[18] S. Shakeel, L. Fiorino, R. Landolfo, Behavior factor evaluation of CFS wood sheathed shear walls according to FEMA P695 for Eurocodes. Engineering Structures, 2020, 221, 111042

[19] L. Fiorino, S. Shakeel, R. Landolfo, Seismic behaviour of a bracing system for LWS suspended ceilings: Preliminary experimental evaluation through cyclic tests. ThinWalled Structures, 2020, 155, 106956

[20] A. Campiche, L. Fiorino, R. Landolfo, Numerical modelling of CFS two-storey sheathing-braced building under shaking-table excitations. Journal of Constructional Steel Research, 2020, 170, 106110 
[21] A. Campiche, Numerical modelling of cfs three-story strap-braced building under shaking-table excitations. Materials, 2021, 14(1), pp. 1-13, 118

[22] V. Macillo, O. Iuorio, M.T. Terracciano, L. Fiorino, R. Landolfo, "Seismic response of Cfs strap-braced stud walls: Theoretical study" Thin-Walled Structures, Vol. 85, pp. 301-312, (2014).

[23] M.T. Giugliano, A. Longo, R. Montuori, V. Piluso, "Influence of homoschedasticity hypothesis of structural response parameters on seismic reliability of CB-frames" Georisk, 5 (2), pp. 120-131, (2011).

[24] R. Tartaglia, M. D’Aniello, G.A. Rassati, (2019). Proposal of AISC-compliant seismic design criteria for ductile partially-restrained end-plate bolted joints. Journal of Constructional Steel Research Volume 159, August 2019, Pages 364-383

[25] R. Tartaglia, M. D’Aniello, M. Zimbru, R. Landolfo, (2018). Finite element simulations on the ultimate response of extended stiffened end-plate joints. Steel and Composite Structures, An International Journal Vol. 27 No. 6, June25 2018. pages 727-745. DOI: 10.12989/scs.2018.27.6.727

[26] R. Tartaglia, M. D'Aniello, R. Landolfo, (2018). The influence of rib stiffeners on the response of extended end-plate joints. Journal of Constructional Steel Research 148 (2018) 669-690.

[27] M. D'Aniello, R. Tartaglia, D. Cassiano, (2020) Experimental Investigation of The Inelastic Tensile Behaviour of Non-Preloadable Grade 8.8 Bolts. Ingegneria Sismica: International Journal of Earthquake Engineering, Volume 37, Issue 2, 2020, Pages 92-110

[28] R. Tartaglia, M. D'Aniello, M. Zimbru, (2020). Experimental and numerical study on the T-Stub behaviour with preloaded bolts under large Deformations. Structures Volume 27, October 2020, Pages 2137-2155 https://doi.org/10.1016/j.istruc.2020.08.039

[29] M. Pongiglione, C. Calderini, M. D’Aniello, R. Landolfo, "Novel Reversible SeismicResistant Joint for Sustainable and Deconstructable Steel Structures" (2021) Journal of Building Engineering, 35, 101989, https://doi.org/10.1016/j.jobe.2020.101989

[30] R. Tartaglia, M. D'Aniello, R. Landolfo, (2020). Numerical Simulations to Predict the Seismic Performance of a 2-Story Steel Moment-Resisting Frame. Materials 2020, 13(21), 4831; doi:10.3390/ma13214831

[31] UNI EN 1993-1: "Eurocode 3: Design of steel constructions". CEN, 2005.

[32] UNI EN 1998-1: "Eurocode 8: Design of structures for earthquake resistance-Part 1: General rules, seismic sctions and rules for buildings". CEN, 2004.

[33] K. Weynand, M. Huter, P. Kirby, L. Simões da Silva, P. Cruz: "SERICON - A Databank for tests on semi-rigid joints". In Proc. of the COST C1 Inter. Conf. on Control of the Semi-Rigid Behaviour of Civil Engineering Structural Connections, pp. 217-228, Liège, Belgium (1998).

[34] RFCS research project European pre-qualified steel joints (EQUALJOINTS - RFSRCT-2013-00021), 2013.07.1-2016.06.31.

[35] RFCS-2016 Valorisation of knowledge for European pre-qualified steel JOINTS (EQUALJOINTS-PLUS - RFSR-AM-02-2016-754048). 
[36] G. D. Porta, I. Russo, E. Nastri, "Preliminary comparison on MRFs and dual systems equipped with extended stiffened connections" (2019) AIP Conference Proceedings, 2116, art. no. 260023.

[37] E. Nastri, P. Tsarpalis, "Seismic analyses of dual concentrically braced frames accounting for the presence of haunched connections" (2019) COMPDYN Proceedings, 1, pp. 73-95.

[38] A. Catapano, E. Nastri, S. Streppone, "Design and analysis of dual EBFs equipped with prequalified connections" (2019) COMPDYN Proceedings, 1, pp. 96-130.

[39] RFCS-2015 FREEDAM Project, (RFSR-CT-2015-00022)

[40] F.M. Mazzolani, V. Piluso, "Theory and Design of Seismic Resistant Steel Frames". E\&FN Spon, E\&FN Spon, an Imprint of Chapman \& Hall, 1996.

[41] F.M. Mazzolani, "Moment Resistant Connections of Steel Frames in Seismic Areas, Design and Reliability". E\&FN Spoon, 2000.

[42] V. Piluso, E. Nastri, R. Montuori, "Advances in Theory of Plastic Mechanism Control: Closed Form Solution for MR-Frames", Earthquake Engineering and Structural Dynamics, 44, Issue 7, pp.1035-1054, (2015).

[43] R. Montuori, E. Nastri, V. Piluso, P. Todisco, “A simplified performance based approach for the evaluation of seismic performances of steel frames", (2020) Engineering Structures, 224, art. no. 111222,

[44] R. Montuori, E. Nastri, V. Piluso, P. Todisco, "Evaluation of the seismic capacity of existing moment resisting frames by a simplified approach: Examples and numerical application" (2021) Applied Sciences (Switzerland), 11(6), art. no. 2594.

[45] R. Montuori, R. Muscatia, "Plastic design of seismic resistant reinforced concrete frame" Earthquake and Structures, 8 (1), pp. 205-224, (2015).

[46] G. Dell'Aglio, R. Montuori, E. Nastri, V. Piluso, "A critical review of plastic design approaches for failure mode control of steel moment resisting frames" Ingegneria Sismica, 34 (4), pp. 82-102, (2017).

[47] R. Montuori, E. Nastri, V. Piluso, M. Troisi, "Influence of connection typology on seismic response of MR-Frames with and without 'set-backs" Earthquake Engineering and Structural Dynamics, 46 (1), pp. 5-25, (2017).

[48] R. Montuori, V. Sagarese, "The use of steel rbs to increase ductility of wooden beams" Engineering Structures, 169, pp. 154-161, (2018).

[49] V. Piluso, A. Pisapia, P. Castaldo, E. Nastri, "Probabilistic Theory of Plastic Mechanism Control for Steel Moment Resisting Frames" Structural Safety, 76, pp. 95107(2019).

[50] RFCS-2020 Valorisation of knowledge for FREE from DAMage steel connections (FREEDAM PLUS - RFSR-AM-02-2019-899321).

[51] K. Lee, C. Vulcu "Numerical investigation on seismic behaviors of steel haunch connections". Study Program: SUSCOS_M, Universitatea Politehnica Timişoara, Romania. $2015 / 2016$ 
[52] F. Di Lauro, R. Montuori, E. Nastri, V. Piluso, "Partial safety factors and overstrength coefficient evaluation for the design of connections equipped with friction dampers" (2019) Engineering Structures, 178, pp. 645-655.

[53] A. Longo, R. Montuori, V. Piluso, "Moment frames - concentrically braced frames dual systems: analysis of different design criteria" Structure and Infrastructure Engineering, 12 (1), pp. 122-141, (2016).

[54] A. Longo, R. Montuori, V. Piluso, "Seismic design of chevron braces cupled with MRF fail safe systems" Earthquake and Structures, 8 (5), pp. 1215-1239, (2015).

[55] A. Longo, R. Montuori, V. Piluso, "Theory of plastic mechanism control for MRF-CBF dual systems and its validation" Bulletin of Earthquake Engineering, 12 (6), pp. 27452775, (2014).

[56] A. Longo, R. Montuori, E. Nastri, V. Piluso, "On the use of HSS in seismic-resistant structures", Journal of Constructional Steel Research, 103, pp. 1-12, (2014).

[57] R. Tartaglia, M. D'Aniello, G. Di Lorenzo, A. De Martino, "Influence of EC8 rules on P-delta effects on the design and response of steel MRF" (2018) Ingegneria Sismica, 35 (3), pp. 104-120.

[58] CEN, Eurocode 8, draft. "Design of structures for earthquake resistance - Part 1-1: General rules and seismic action", 2020a.

[59] CEN, Eurocode 8 draft:"Design of structures for earthquake resistance - Part 1-2: Rules for new buildings", 2020.

[60] CSI 2007. SAP 2000, "Integrated Finite Element Analysis and Design of Structures. Analysis Reference.," Computer and Structure Inc. University of California, Bekerley.

[61] M. D’Aniello, G. La Manna Ambrosino, F. Portioli, R. Landolfo, “Modelling aspects of the seismic response of steel concentric braced frames" Steel and Composite Structures, An International Journal, 15(5), pp. 539-566, (2013).

[62] S. Costanzo, M. D'Aniello, R. Landolfo, "The influence of moment resisting beam-tocolumn connections on seismic behavior of chevron concentrically braced frames", Soil Dynamics and Earthquake Engineering, 113, pp. 136-147, (2018).

[63] S. Costanzo, M. D'Aniello, R. Landolfo, "Seismic design criteria for chevron CBFs: Proposals for the next EC8 (part-2)" Journal of Constructional Steel Research, 138, pp. 17-37, (2017).

[64] S. Costanzo, M. D’Aniello, R. Landolfo, "Seismic design criteria for Chevron CBFs: European vs North American codes (Part-1)" Journal of Constructional Steel Research, 135, pp. 83-96, (2017).

[65] S. Costanzo, M. D'Aniello, R. Landolfo, "Critical review of seismic design criteria for chevron concentrically braced frames: The role of the brace-intercepted beam" Ingegneria Sismica, 33 (1-2), pp. 72-89, (2016).

[66] S. Costanzo, M. D'Aniello, R. Landolfo, "The influence of beam stiffness on seismic response of chevron concentric bracings" Journal of Constructional Steel Research, 112, pp. 305-324, (2015).

[67] UNI EN 1998-3: "Eurocode 8: Design of Structures for Earthquake Resistance-Part 3: Evaluation and adaptation of buildings", CEN, 2004. 
[68] D. Georgescu "Earthquake-Recent developments in theoretical and experimental results in steel structures", Seismic resistant braced frames, 1996.

[69] D. Vamvatsikos, C.A. Cornell, "Incremental dynamic analyses". Earthquake Engineering and Structural Dynamics, 2002.

[70] L. Luzi, R. Puglia, E. Russo \& ORFEUS WG5 (2016). Engineering Strong Motion database (ESM), version 1.0. Istituto Nazionale di Geofisica e Vulcanologia. Observatories \& Research Facilities for European Seismology. doi: 10.13127/ESM, FEMA-355F: "State of Art Report on Performance Prediction and Evaluation of Steel Moment-Frame Buildings". Federal Emergency Management Agency/September, 2000, 4 - 25-30. 